Case Study

\title{
The Feasibility Study to Improve the Efficiency of Municipal Water Supply
}

\section{Kentsel Su Temininin Verimliliğinin Artırılmasına İlişkin Fizibilite Çalışması}

\author{
Mehmet Can Güçlü ${ }^{*}$, Burak Ekinci ${ }^{1}$, Aslıhan Korkmaz ${ }^{1}$, Yusuf Başaran ${ }^{1}$, Yakup Karaaslan ${ }^{1}$, \\ Serdar Aldemir ${ }^{2}$, Ayhan Türkoğlu², Ali Serindağ ${ }^{2}$, Jose Alberto Colıno Fernandez ${ }^{3}$, Kerem Ar ${ }^{4}$, \\ Baki Ülgen ${ }^{2}$, Bilal Dikmen ${ }^{1}$, Bekir Pakdemirli ${ }^{5}$ \\ ${ }^{1}$ Ministry of Agriculture and Forestry, General Directorate of Water Management, 06510, \\ Yenimahalle-Ankara/Turkey \\ mehmetcan.guclu@tarimorman.gov.tr (https://orcid.org/0000-0002-9347-3573), \\ burak.ekinci@tarimorman.gov.tr (https://orcid.org/0000-0003-0981-5321), \\ aslihan.korkmaz@tarimorman.gov.tr (https://orcid.org/0000-0002-5983-6748), \\ basaran.yusuf@tarimorman.gov.tr (https://orcid.org/0000-0002-6662-3265), \\ yakup.karaaslan@tarimorman.gov.tr (https://orcid.org/0000-0001-8993-4771), \\ bilaldikmen@tarimorman.gov.tr (https://orcid.org/0000-0002-8333-5310) \\ ${ }^{2}$ Muğla Water and Sewerage Administration, 48050, Menteşe-Muğla/Turkey \\ serdar.aldemir@muski.gov.tr (https://orcid.org/0000-0002-6681-0140),
} ayhan.turkoglu@muski.gov.tr (https://orcid.org/0000-0002-2075-231X), ali.serindag@muski.gov.tr (https://orcid.org/0000-0002-3283-2181), baki.ulgen@muski.gov.tr (https://orcid.org/0000-00031564-2332)

${ }^{3}$ TYPSA, 28703, San Sebastián de los Reyes-Madrid/Spain jacolino@typsa.es (https://orcid.org/0000-0002-7191-2221)

${ }^{4}$ DOLSAR Mühendislik, 06530, Çankaya-Ankara/Turkey

kerem.ar@gmail.com (https://orcid.org/0000-0001-7048-3392)

${ }^{5}$ Ministry of Agriculture and Forestry, 06800, Çankaya-Ankara/Turkey

bekir.pakdemirli@tarimorman.gov.tr (https://orcid.org/0000-0002-0336-0613)

Received Date: 02.06.2020, Accepted Date: 16.10.2020

\begin{abstract}
The feasibility study was designed to assess water efficiency in municipal water supply systems. The total amount of produced and distributed water was 14,184,650 $\mathrm{m}^{3}$ in 2018 for 79,296 people in Marmaris. Nonetheless, the volume of billed water was only $8,131,491 \mathrm{~m}^{3}$; therefore, the non-revenue water percent was $42.7 \%$ involving unbilled authorized consumption (5.1\%), physical losses (28.9\%), and administrative losses (8.7\%). According to projections, water demand including the losses was $14,184,650 \mathrm{~m}^{3}$ in 2018 , and is expected to increase to $22,204,429 \mathrm{~m}^{3}$ in the without-project scenario whereas it would reach $19,852,469 \mathrm{~m}^{3}$ in the with-project scenario by the year 2038. Consequently, five measures were proposed; establishing district metered areas and pressure management areas, infrastructure development, updating and extending Supervisory Control and Data Acquisition Systems, and other complementary measures to improve the efficiency of the water supply system.
\end{abstract}

\footnotetext{
${ }^{*}$ Corresponding author
} 
Mehmet Can Güçlü, Burak Ekinci, Aslıhan Korkmaz, Yusuf Başaran, Yakup Karaaslan,

Serdar Aldemir, Ayhan Türkoğlu, Ali Serindă̆, Jose Alberto Colino Fernandez, Kerem Ar, Baki Ülgen, Bilal Dikmen, Bekir Pakdemirli

Turkish Journal of Water Science \& Management 5 (1) (2021) / 2 - 39

Applying the proposed actions would reduce the total water losses from $37.6 \%$ to $24.7 \%(19.9 \%$ physical, $4.8 \%$ administrative) in 2023 , and the value would reach $20.3 \%$ (18\% physical, $2.3 \%$ administrative) in 2038. This study presents that the proposed investment's estimated total cost is $€$ $2,956,739.26$ and is foreseen to be implemented throughout 2021 and 2022. The Payback Period of the investment is 5.5 years (2027), and the Discounted Payback Period is 6.8 years (2028). The assessment shows that the unitary cost of water evolves from $1.31 € / \mathrm{m}^{3}$ in the current situation to 1.00 $-1.30 € / \mathrm{m}^{3}$ in 2038 , based on the scenario selection (with-/without- project scenario) and the investment distribution periods.

Keywords: Municipal water supply, water use efficiency, water losses management, hydraulic modeling

\section{$\ddot{\mathbf{O} z}$}

$\mathrm{Bu}$ fizibilite çalışması, kentsel su temini sistemlerindeki su verimliliğini değerlendirmek üzere hazırlanmıştır. Marmaris'te 2018 yılında 79.296 kişi için üretilip dağıtılan toplam su miktarı 14.184.650 $\mathrm{m}^{3}$ 'tür. Öte yandan, faturalandırılan su miktarı yalnız $8.131 .491 \mathrm{~m}^{3}$ olduğundan gelir getirmeyen su oran $1 \% 42,7^{\prime}$ dir. Gelir Getirmeyen $\mathrm{Su}$; faturalandırılmayan izinli tüketimleri $(\% 5,1)$, fiziki kayıpları $(\% 28,9)$ ve idari kayıpları $(\% 8,7)$ kapsamaktadır. Su kayıpları da dâhil olmak üzere toplam su ihtiyacına ilişkin değerlerin 2018 yılında yıllık $14.184 .650 \mathrm{~m}^{3}$ su üretimiyle başlayıp 2038 yılında projesiz senaryo için $22.204 .429 \mathrm{~m}^{3}$, projeli senaryo için ise $19.852 .469 \mathrm{~m}^{3}$ olacağ öngörülmektedir. Bu çalışmadan elde edilen bulgular neticesinde su kullanımındaki verimliliği artırmak için izole alt bölgelerin oluşturulması, basınç yönetimi alanlarının oluşturulması, altyapının iyileştirmesi, Veri Tabanlı Kontrol ve Gözetleme Sisteminin güncellenmesi, genişletilmesi ve diğer tamamlayıc tedbirler olmak üzere 5 tedbir önerilmektedir. Bu tedbirlerin uygulanması sonucunda 2018 yılında \%37,6 değerindeki toplam su kayıpları 2023 yılında \%24,7 (fiziki kayıp \%19,9 ve idari kayıp \%4,8), 2038 yılında \%20,3 değerine ulaşabilecektir (\%18 fiziki kayıp ve \%2,3 idari kayıp). Önerilen yatırımın tahmini toplam maliyeti $2.956 .739,26 €$ olup yatırımın 2021 ve 2022 yıllarında yapılması öngörülmektedir. Yatırımın geri ödeme süresi 5,5 yıl (2027) ve iskontolu geri ödeme süresi 6,8 yıldır (2028). Sonuçlar mevcut durumda $1,31 € / \mathrm{m}^{3}$ olan suyun birim maliyetinin senaryo seçimi (projeli/projesiz senaryo) ve yatırım dağıtım periyotlarına göre 2038 yılında 1,00-1,30 €/ $/ \mathrm{m}^{3}$ aralı̆̆ında değişeceğini göstermektedir. hidrolik modelleme

Anahtar kelimeler: Kentsel su temini, su kullanım verimliliği, su kayıplarının yönetimi,

\section{Introduction}

Socioeconomic developments and increasing climate change pressures negatively affect water resources and raise concerns about water scarcity (Kummu et al., 2016). Specifically, the Mediterranean region was pointed out as a threatened area for water scarcity in the near future. Therefore, water utilities should have a highly efficient process to sustain a sufficient water supply quantity (Muhammetoğlu et al., 2018). Hence, minimizing water losses especially in the water distribution system plays a key role in getting the maximum benefit from a unit of produced water in an efficient municipal water supply system. Getting attention to water loss may be difficult because it is mostly invisible, and it may negatively impact 
government budgets, environmental resources, and user's health. The varieties of impacts can help to increase attention on the importance of real costs associated with water losses from the municipal water supply system. For instance, water losses; 1) represent a lost opportunity to supply much water for a city, 2) increase the cost, 3) increase stress on aquatic ecosystems, 4) reduce the reliability of the water supply system, 5) increase pipe failures and 6) leaks in water pipes may reduce the water quality and threaten the user's health (Renzetti \& Dupont, 2013). These possible impacts show that water loss must be controlled to prevent or reduce its negative impacts. Herewith water losses can be considered as one of the main problems in the water supply systems (Karadirek et al., 2012). Water leakage rates in the water distribution systems were found to be changed from 3-7\% in well- maintained systems in the Netherlands to around 50\% in some developing countries with less well-maintained systems, and the amount of leaked water depends on the type of leak, pressure, pipe material, water demand, and soil hydraulics (Puust et al., 2010). To illustrate, high pressures because of the hilly topography of Hong Kong, there are many difficulties to maintain the network sustainably. The replacement and rehabilitation of the aging pipelines and blocking the main leakages were some of the most useful ways to improve the efficiency of the system. After a water loss management program in Hong Kong, the leakage ratio was reduced from more than $25 \%$ in 2000 to about 15\% in 2019 (WSD-Water Loss Management, n.d.). Leaks can occur in the storage (reservoirs and tanks), distribution systems, and service connections up to the point of metering.

The distribution leakages can be classified as background leaks, burst related leaks; which caused by many reasons; bad pipe connections, pipe corrosions, mechanical damages, ground conditions and movement, high system pressure, pipe age, defects in pipes, winter temperatures, damage due to excavation and poor workmanship (Khadam et al., 1991; Puust et al., 2010). Due to the difficulties of monitoring and projecting a real network system, simulation models are largely used to manage water distribution systems better. Therefore, several hydraulic models have been used either freeware (e.g., EPANET) or licensed software (e.g., WaterGEMs, WaterCAD) (Awe et al., 2019). EPANET is useful software for complex and conceptual studies; on the other hand, a licensed software usually has more user-friendly features. These simulators can be useful to reveal system requirements and do planning for improvements of the system's utilities (Terlumun \& Robert, 2019). Modeling water quantity and quality using hydraulic models could improve the efficiency of municipal water supply.

District Metered Areas (DMAs) and Pressure Management Areas (PMAs) are one of the most advantageous and significant ways to reduce leakage in the water 
supply systems. The creation of the DMA in a complex water system consists of identifying areas that can be isolated by closing the corresponding valves. DMA allows detecting and monitoring possible leakages within its boundaries and it is a well-known and extensively used system to decrease physical losses in water networks. These establishments are guiding to understand water consumption and water losses in a network. Common practices recommend that a DMA should include 500 to 3,000 properties (service connections) in urban networks (Gomes et al., 2015). Besides, DMAs would substantially reduce leakage awareness time and are a prerequisite for effective prioritization of leak detection and repair activities. Pressure management through the creation of the PMAs is another significant way to reduce leakages in the system due to the relationship between pressure and leakage. The second benefit is the decrease in the number of bursts in the network, and an increase in the lifespans of assets. Excessive pressures and pressure fluctuations can be prevented by pressure management. Elevation deviations in topography have crucial impacts during establishing PMAs. PMAs aim at ensuring optimum pressures to the distribution network homogenously. In addition to the water quantity analyses, water quality analyses (i.e., water age and residual chlorine) could be done by using the aforementioned models. All these should be considered to control water losses and to reduce water quality concerns in municipal water supply systems.

This study focuses on a feasibility assessment on water efficiency in a municipal water system to provide technical assistance on the improvement of water efficiency in Turkey. The main objective of this study was to analyze in-depth the use of water at the municipal level in Marmaris to assess water use efficiency, the practices in water pricing (tariffs), and finally propose more appropriate measures to improve both the efficiency and the pricing. There are several problems in the Marmaris water supply system regarding leakages and operational difficulties. Thus, the system needs to be rehabilitated not to exceed the water loss limit determined bylaw of "Control of Water Losses in Drinking Water Supply and Distribution Systems" published on $8^{\text {th }}$ May 2014, Official Gazette of the Republic of Turkey No. 28994, which Article 9 was amended by the by-law of $31^{\text {th }}$ August 2019 (Official Gazette of the Republic of Turkey, No. 30874). According to the by-law, total water losses [physical loss (real loss) and administrative loss (apparent loss)] in metropolitan municipalities should be less than $30 \%$ as of 2023 and less than $25 \%$ by 2028 . This study assesses the current status of the municipal water supply system in Marmaris within the context of physical losses, administrative losses, and management of the system to build an implementation of an action plan for water efficiency. Within this purpose, the theoretical framework of this assessment consists of all municipal water system beginnings from water production to water reuse in the study area. Lastly, 
actions were identified as the program of measures to improve municipal water use efficiency, and the knowledge was used to develop action plans at the river basin level and to prepare methodological guidance documents.

\section{Method}

This study was conducted within the activity of the municipal sector feasibility study on water efficiency under the 3 RBMP project ${ }^{1}$. The target year of the project is 2038 and the planning cycles of the project are in line with the Water Framework Directive (WFD).

In this study, we assessed the current status of the municipal water supply system within the context of physical losses, administrative losses, and water system management to make an action plan for water efficiency. Figure 1 illustrates the main work packages of this study step-by-step. After assessing the current status, first, some measures were proposed in terms of physical losses by using a hydraulic model, i.e., district metered areas, pressure management areas, and infrastructure rehabilitation. Second, administrative loss reduction plans, integrated customer meter management, and illegal connection control plans were proposed to deal with administrative losses. Third, water system management was explored by the extension of the Supervisory Control and Data Acquisition (SCADA) Systems, developing the capacity building plans and saving water public awareness campaigns, and tariff-related measures. Finally, the findings from previous studies were used to implement an action plan.

\section{Diagnosis of the Current Situation}

Figure 2 depicts a summarizing diagram of the municipal water system of the study area. The total amount of water used in Marmaris comes from the Marmaris Atatürk Dam; a concrete faced rockfill dam with a total capacity of $25.56 \mathrm{Hm}^{3}$. The water is transmitted from the dam to a raw water pumping station by a diversion channel. After that point, water is conveyed by a DN1000 steel pipe to the valve chamber. Two valves discharge water to a creek and one valve diverts the water to the raw water pumping station. Then, the raw water is pumped to the drinking water treatment plant (DWTP). The DWTP process is conventional and no advanced processes are applied. Produced water is pumped to the Beldibi water storage tank with $5,000 \mathrm{~m}^{3}$ for serving water to the Beldibi neighborhood and main storage tanks

\footnotetext{
${ }^{1}$ Technical Assistance on Economic Analyses within River Basin Management Plans and Water Efficiency Aspects in 3 Pilot River Basins in Turkey (3 RBMP).
} 
(Marmaris with 5,000 $\mathrm{m}^{3}$, Armutalan with $3,000 \mathrm{~m}^{3}$, and İçmeler with $3,000 \mathrm{~m}^{3}$ ). From storage tanks, the water is supplied mainly by gravity directly to final consumers or small deposits of certain neighborhoods. The total length of the transmission and distribution lines is around $270 \mathrm{~km}$. When water is transferred, and used by final consumers, then wastewater is transferred to the wastewater treatment plant (WWTP).

\section{Figure 1}

The Content of the Feasibility Study

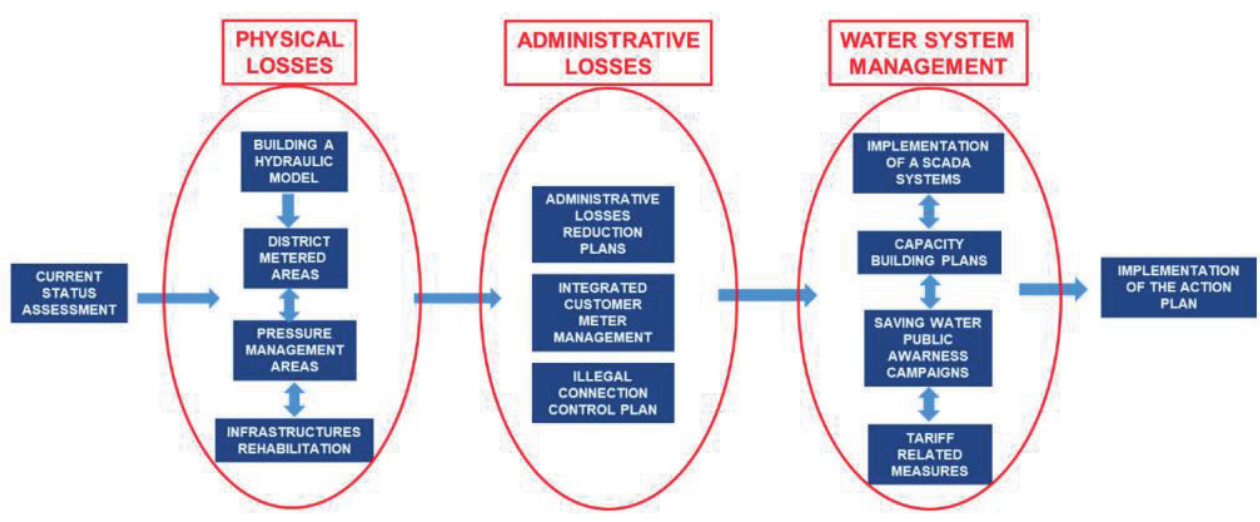

\section{Figure 2}

Municipal Water Supply in Marmaris

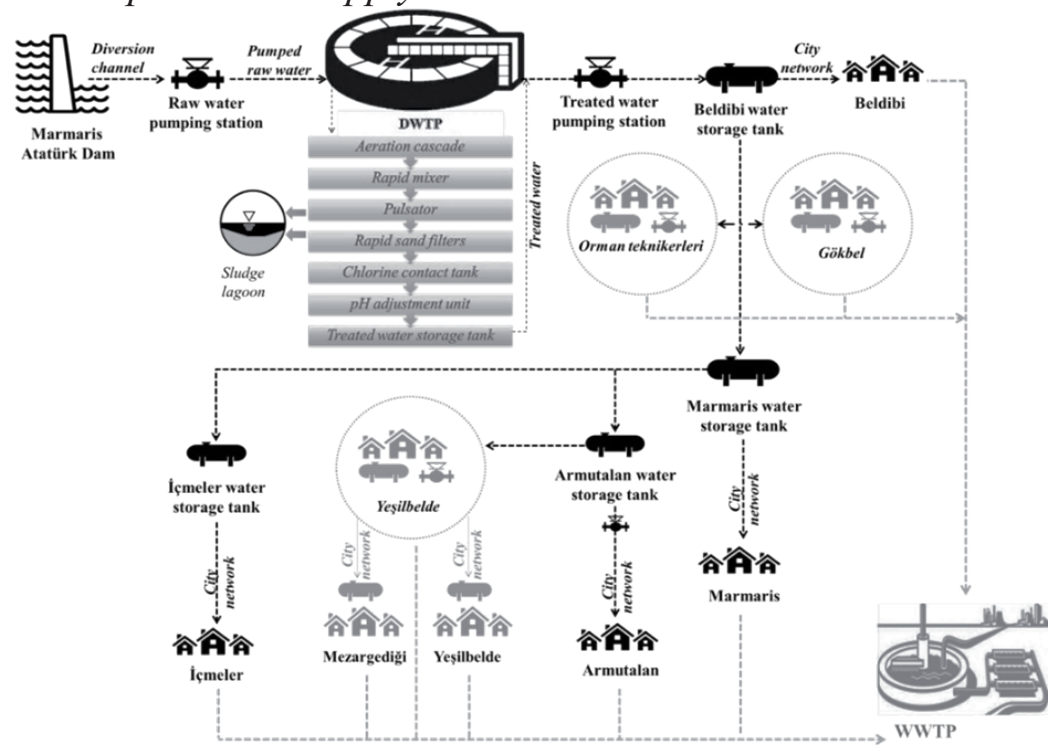


Throughout the study, the average yearly production of the DWTP was $56,160 \mathrm{~m}^{3} /$ day, but it sometimes reached $60,000 \mathrm{~m}^{3} /$ day in 2018 . The water efficiency of the DWTP during water production was quite high $(99.5 \%)$ due to the high quality of the raw water in 2018. The outlet pipe meter was not working; therefore, Muğla Water and Sewerage Administration (MUSKI) measured by subtracting the amount of backwashing and sludge removal from the amount of inlet water on a daily basis. All the components and parameters were identified to assess the current situation. Then, calibrated flow meters were installed on the outlet pipes of three main storage tanks (Marmaris, Armutalan, İçmeler) to evaluate the current status of the distribution network in terms of physical losses, daily and seasonal consumption patterns, and storage tank capacities. Measurements provided by these flow meters were very practical to evaluate the current status of the distribution. The data included maximum and minimum flows come from the storage tanks and average flow rates daily. Totalized volumes were also taken from June 1 to December 31 in 2018. Although the SCADA has been operated in the past, MUSKI has only provided data since the calibration of flow meters and their connection to the provincial SCADA.

\section{Efficiency Indexes and Ratios}

An approach to assess the diagnosis of the water sector in the pilot area was to be a utilization of different well-known efficiency ratios and indexes. They allow us to compare those calculated values with similar systems at the international level. The water production index, non-revenue water (NRW) ratio assessment, administrative losses, physical losses were calculated. To be able to calculate all the ratios and indexes, a comprehensive data collection was done with the support of MUSKI responsible staff both in Marmaris and Muğla. The values of the main variables used for those calculations are; total water abstraction ( $\mathrm{m}^{3} /$ year), system input volume $\left(\mathrm{m}^{3} /\right.$ year), billed consumption $\left(\mathrm{m}^{3} /\right.$ year $)$, total physical losses $\left(\mathrm{m}^{3} /\right.$ year), total administrative losses $\left(\mathrm{m}^{3} /\right.$ year), the total length of water distribution $(\mathrm{km})$, the total number of water connections, the average length of service connections $(\mathrm{km})$, average operating pressure $(\mathrm{mWC})$, total wastewater treated in the wastewater treatment plant $\left(\mathrm{m}^{3} /\right.$ year), total reused treated wastewater $\left(\mathrm{m}^{3} /\right.$ year). Accordingly, two main assessments (NRW and Physical loss) were done based on calculations. International NRW Assessment Matrix for the NRW assessment and Physical Loss Assessment Matrix for the physical loss assessment were used to determine the technical performance categories (Liemberger \& McKenzie, 2005; Liemberger, 2010). Matrices and category definitions can be seen in the appendix (Table A1 and Table A2). 
Infrastructure leakage index (ILI) is an index that was first introduced in 1999, and since then it has been used as a standard index to determine the performance efficiency within municipal water infrastructures in many countries (Liemberger \& McKenzie, 2005). It is calculated by dividing the Current Annual Real Losses (CARL) and the Unavoidable Annual Real Losses (UARL) (equation 1). CARL is the actual loss happening in the system. UARL is the technically lowest achievable annual real losses for a well maintained and well-managed system. International Water Association (IWA) Task Forces have developed a 'user-friendly' pressure-dependent formula for predicting UARL values in a wide range of distribution systems (equation 2) (Lambert et al., 1999; Liemberger \& McKenzie, 2005):

$$
\mathrm{ILI}=\mathrm{CARL} / \mathrm{UARL}
$$

where CARL is Current Annual Real Losses (1t/day); UARL is Unavoidable Annual Real Losses (1t/day).

$$
\operatorname{UARL}(1 \mathrm{t} / \text { day })=(18 \times \mathrm{Lm}+0.8 \times \mathrm{Nc}+25 \times \mathrm{Lp}) \times \mathrm{P}
$$

where Lm is mains length $(\mathrm{km})$; Nc is number of service connections; Lp is the total length of underground pipe between the edge of the street and customer meters $(\mathrm{km})$; $\mathrm{P}$ is average operating pressure $(\mathrm{mWC})$.

\section{Model Building}

WaterCAD (CONNECT Edition Update 2 [10.02.00.43]) licensed hydraulic model software was used as an analytical tool to simulate projections and to propose measures to improve efficiency in the system. The necessary input data was prepared to run simulations such as a digital map of the network, population projections, and water demands per the scenarios in this project.

To evaluate the water distribution network of Marmaris, various scenarios were used throughout modeling: 2018 Winter and 2038 Summer. Solutions for the network's problems were found according to the scenarios, which represent the behavior of the water network under different conditions. The main scenarios used are:

- The current situation, current water infrastructure and current demands (2018), used for calibration,

- Proposed measures related to the water infrastructure, current demands (2018), 
- Proposed measures related to the water infrastructure, future demands (2038).

Population projections, water demands, water subscribers, and tariffs were evaluated to build a model for an efficient water supply. The population trend of the study area was evaluated from 2016 to 2038 for estimating the water demand until the target year of the 3 RBMP project. İlbank, arithmetic, and logistic-curve methods were used for population projections. Among these methods, the İlbank method showed the best fit for the previous trends, so the İlbank method with a constant increment rate (2.76) was selected for the population forecast for Marmaris city centre (Figure 3). Population forecasts of other neighborhoods can be seen in the appendix (Table A3). Then, water demands for different consumer types, and the impacts on the physical status of the municipal water supply system of the increasing population in the study area were estimated.

\section{Figure 3}

\section{Population Projection Methods for Marmaris City Centre}

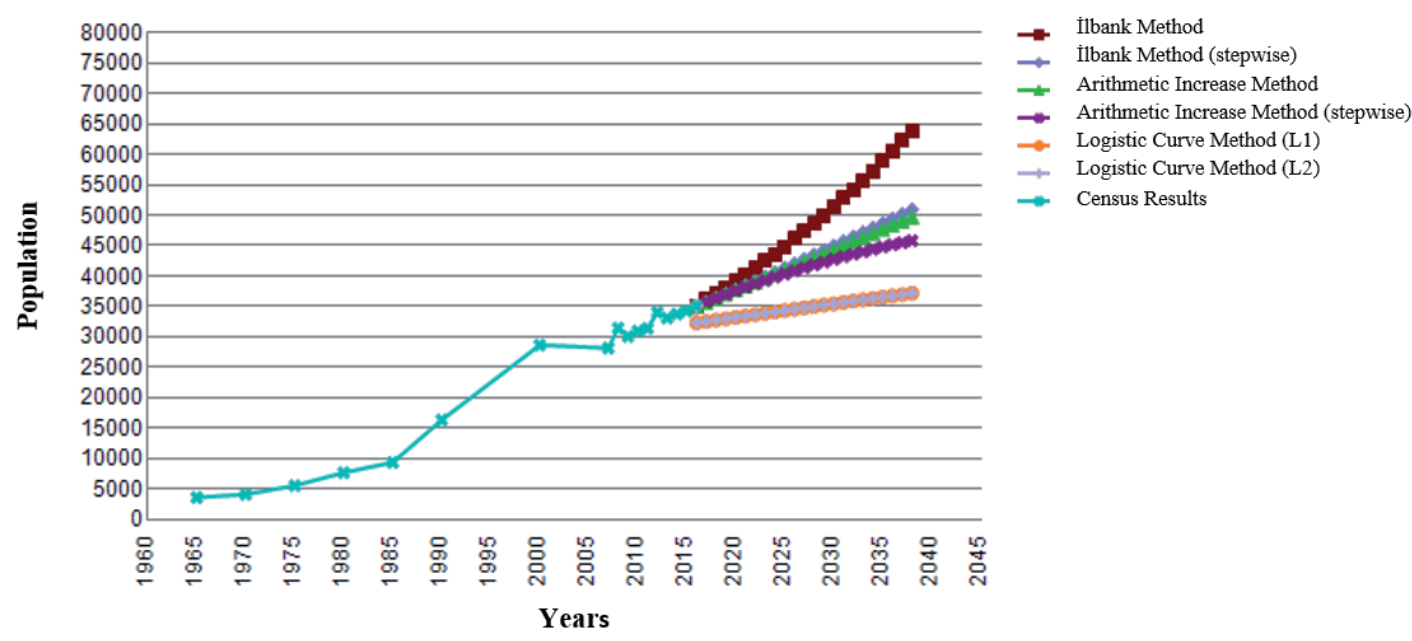

The system in the selected area is expected to meet water demand until 2035 by the without-project scenario. In that year, water subscribers in the network would have less available water compared to their demand. Furthermore, water shortages in the high seasons might be seen, profoundly, even earlier than 2035. Implementing the project is favorable to reduce water losses and retain the present status of the system in the future as well. When the project is performed, the water supply in the selected area would meet future demands until 2038 by accomplishing the objective 
of physical water loss mitigation. To illustrate, gross water consumption is expected to be 465 liters per capita per day (lcd) in 2035 for the without-project scenario, while it is $411 \mathrm{lcd}$ for the with-project scenario. DWTP and pumping stations do not require any investments for increasing the capacity; however, the rest of the water supply system excluding DWTP and pumping station requires an expansion to meet the connected subscriber ratio of $100 \%$.

The creation of the DMA in a complex water system consists of identifying areas that can be isolated by closing the corresponding valves. It is also possible to precisely know the inflow rate and the served water by respectively metering the flow rate in the inlet point and reading the subscribers' meters. DMAs were established to detect and monitor possible leakages within their boundaries and it is a well-known and extensively used system to decrease physical losses in the water distribution network. In order to control the pressure in the network, PMAs were established. There are various Pressure Reduction Valves (PRV) in the market, and the model was run based on two alternatives (PRV active and PRV inactive). As the physical losses were modeled based on the pressure-dependent demands, the influence of the PRV can be observed by the flow amounts from the storage tanks. In addition to the quantity analyses, quality analyses were simulated for the proposed system: water age and residual chlorine.

\section{Water Consumption}

\section{Billing.}

Figure 4 shows the distributions of both subscribers' type and water consumers. The total number of subscribers was 30,947 and residential consumers $(80 \%)$ were the major subscribers of the existent connections, and it was followed by workplace subscribers (16\%) in 2018. Nevertheless, the highest amount of water was consumed by workplaces (46\%), following by residential water consumption $(42 \%)$. The latest billed water volumes were analyzed to assess the water consumption trends of the main towns in the study area. Monthly billing is solely applied in Marmaris City Centre. The rest of the neighborhoods apply bi-monthly billing. 


\section{Figure 4}

\section{Distribution of Water Subscribers and Their Consumptions}

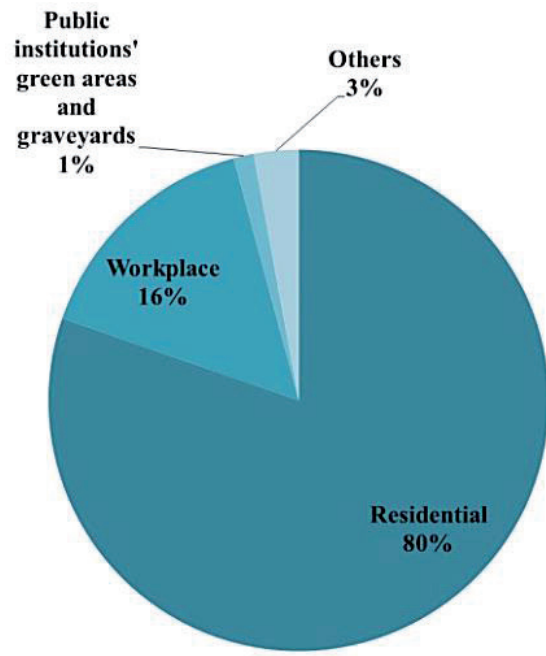

Distribution of subscriber types

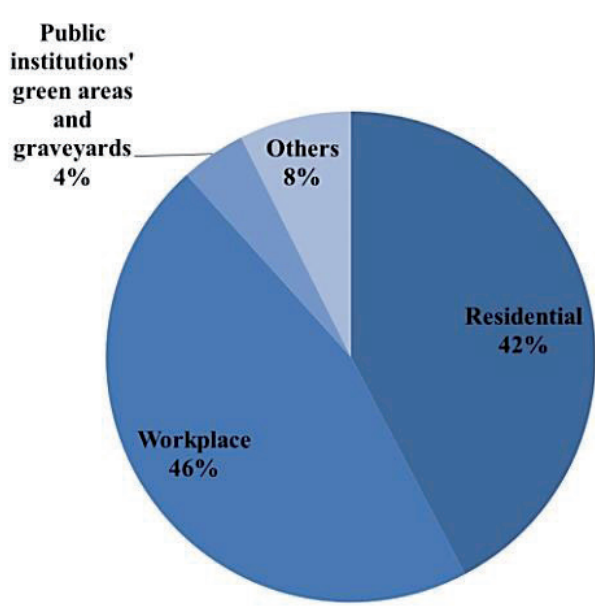

Distribution of water consumptions

\section{Water Balance}

The standard water balance table was prepared for Marmaris for the year 2018. As the production values are certain and physical loss values were estimated based on the flow meter readings from the SCADA, and unbilled authorized consumption, illegal consumption, and unauthorized consumption rates were assumed. According to the information provided by MUSKİ, there was an active unauthorized connection detection policy. This means the unauthorized consumption rate decreased from $20 \%$ of total water production to around $5 \%$ through on-site inspections and measurements. Although the water consumption of the mosques and parks were generally metered, it was assumed that $5 \%$ of total production is consumed by such users. This assumption results in a yearly unbilled authorized consumption volume larger than the billed institutional consumption. However, it should be noted that irrigation of public gardens and green areas requires an excessive amount of water due to the hot climate of Marmaris during summer. Furthermore, metering inaccuracies were assumed to have a typical value of $6 \%$ as under-reading. Figure 5 shows the results of the water balance study. The total water produced and distributed in the case area in 2018 was 14,184,650 $\mathrm{m}^{3}$, while the billed water was $8,131,491 \mathrm{~m}^{3}$, which resulted in a Non-Revenue Water ratio of $42.7 \%$. 
The breakdown of this NRW was the following: Unbilled authorized consumption with 5.1\%, Physical Losses with 28.9\%, and Administrative Losses with $8.7 \%$.

The main assumptions in the water balance study were the amount of unbilled authorized consumption and unauthorized consumption, as well as the metering inaccuracies. The predicted values were assumed to be uniformly distributed within all neighborhoods and subscriber types according to their demands. In the modeling studies, domestic and institutional water consumptions of the city were evaluated together on a population-based approach and commercial consumptions were evaluated separately based on an aerial-based approach.

\section{Figure 5}

Standard Water Balance Table for Marmaris in 2018 (Official Gazette of the Republic of Turkey, 2014)

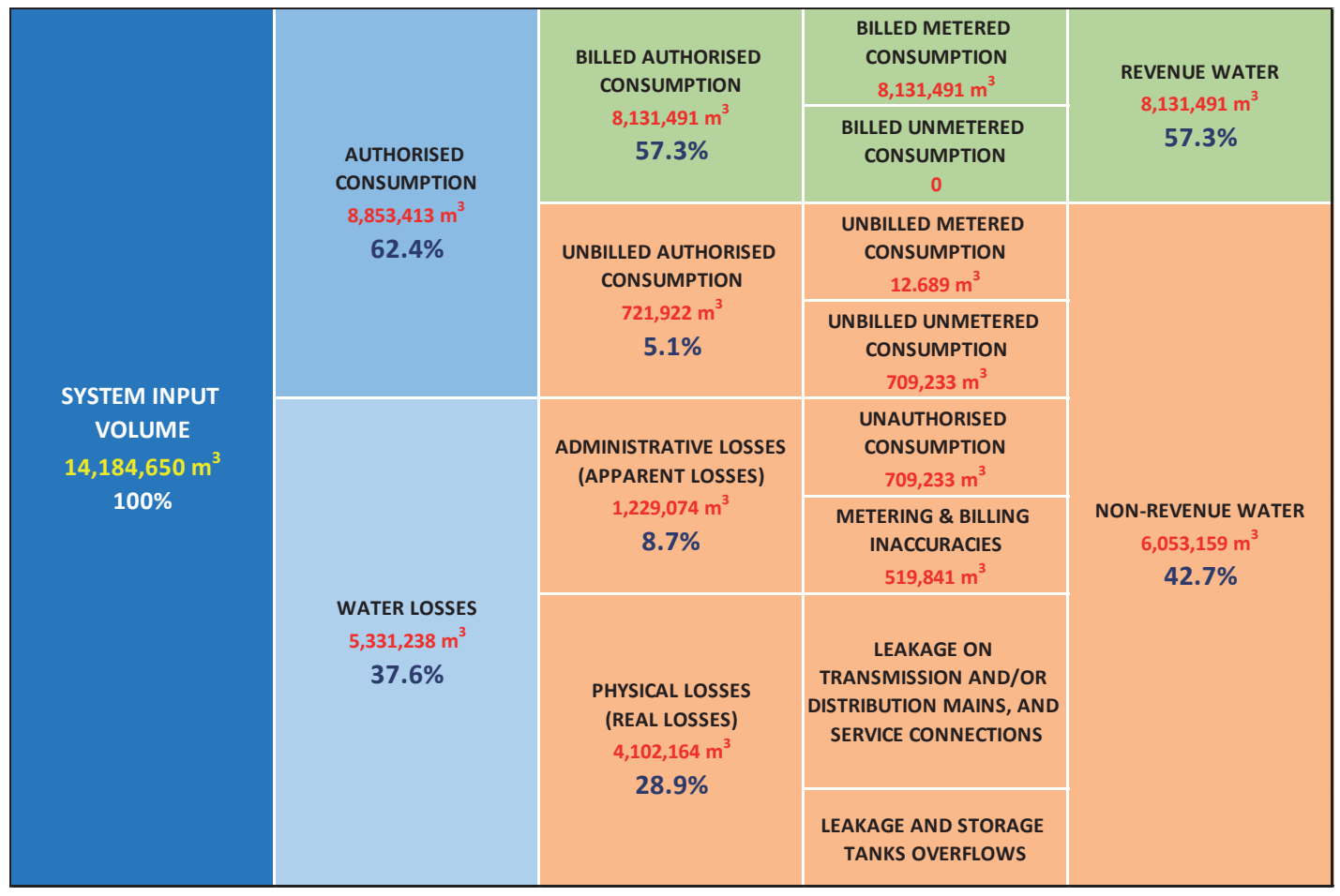




\section{SCADA Systems}

The current status of SCADA Systems was analyzed within all the water facilities containing the SCADA system such as the dam, the raw water pumping stations, the water treatment plant and its pumping station, the storage tanks, and the intermediate pumping stations. The main objectives of the SCADA implementation are given in Figure 6.

\section{Figure 6}

The Main Objectives of the SCADA

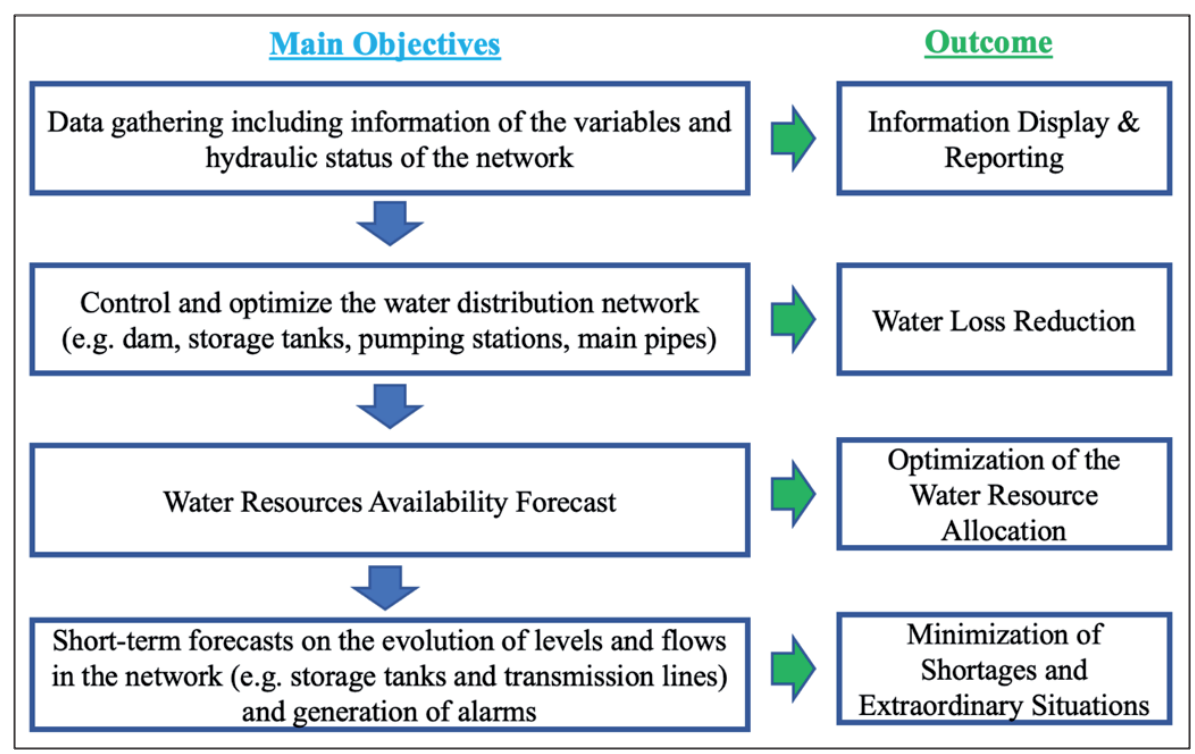

The current status of the SCADA in the study area indicates remote monitoring of storage tanks and pumping stations, automatic control of the pumping stations in accordance with the level of the tanks, monitoring of the flow rates by the electromagnetic flow meters, monitoring the water pressure in the pumping stations by the pressure transmitters, monitoring the residual chlorine devices in the chlorination locations, control and monitoring systems over operator panel (HMI) for local users, alarm monitoring and verification, and tabular and graphical reporting including time-event based and statistical reporting. There is a total of 36 control panels (20 wells, 6 pumping stations, and 10 storage tanks) in the current SCADA control system. 


\section{Financial Analysis}

\section{Cost-benefit analysis.}

The Cost-Benefit Analysis (CBA) is an economic tool to assess the balance between the benefits of an investment and its costs. The purpose of CBA is to facilitate a more efficient allocation of resources by analyzing the suitability for the society of an attempt rather than possible alternatives. CBA is an input for the decision-making process. The financial indicators involved in the analysis as follows: population and water demand, fixed and variable costs of the water supply and wastewater services, billed and collected water/wastewater from different subscribers, applied tariffs, and collected revenues.

The CBA concentrates on the financial analysis of the necessary investment to implement the measures proposed in the study regarding two aforementioned scenarios:

- The without-project scenario states that certain measures for higher water use efficiency were not applied in the pilot area.

- The with-project scenario states that the proposed measures were applied and its financial impact was analyzed.

\section{Unitary price.}

A financial model was developed to understand the relationship between the project variables (e.g., investment cost, population change, water demand pattern) and the emergent financial performance. For this purpose, the financial modeling study indicates four steps:

1. Definition of the base year parameters (e.g., data collection for the year 2018).

2. Definition of the future values for different parameters (e.g., capital expenditures, fixed $\&$ variable costs in line with the capacity requirements, operation \& maintenance, investment costs).

3. Determination of the financial performance indicators (e.g., calculations of the Net Present Value, Interest Return Rate, Payback Period).

4. Finally, an analysis of the unitary cost of the water service concerning water use efficiency was performed. 


\section{Results and Discussion}

\section{Current Status Assessment}

Water consumptions in the project area showed a considerable change from winter to summer because of seasonal population changes, where summer consumptions were 1.57 times higher than the winter consumptions. The value is generally taken as 1.30-1.50 in design works. Daily trends also show changes seasonally. The network's physical loss ratio was estimated at approximately $30 \%$ depending on the flow meter readings from the Marmaris storage tank through the current SCADA. Although it was not surprising to have such a loss rate in a relatively new ductile iron network, the level of leakage was far beyond the standard networks in Turkey, even in well-developed cities. According to the similar measurements from the outlet of the other three storage tanks, physical losses were calculated as follows: about $70 \%$ in Armutalan during the low season $(24 \%$ during the peak season); about $75 \%$ in İçmeler during the low season (17\% during the peak season); however, 2012 data was used to evaluate physical losses in Beldibi because of the lack of added flow meter on the outlet pipe. Therefore, data was analyzed through a $\mathrm{CAD}$ software, and the physical losses were estimated as 50\% during the low and peak season, and it would not likely reduce during peak season because Beldibi had an inland water consumption trend, unlike İçmeler or Armutalan. The amount of leakage was expected to decrease because consumption nearly doubled and network pressures were lowered even at night during the tourism season. It can easily be indicated that water consumption in the Marmaris network was considerably more than the Armutalan network. The net consumption/total consumption ratio remarkably went up during the summer season. Furthermore, the approximative value of the maximum physical loss is assumed to be decreased during peak season. Seasonal changes in physical loss ratios showed that the physical loss ratio was profoundly based on water consumption because of the pressure reductions in the network in parallel with the consumption decreases. Water consumption in the Marmaris network $\left(19,391 \mathrm{~m}^{3} /\right.$ day $)$ was more than İçmeler network $\left(9,832 \mathrm{~m}^{3} /\right.$ day $)$. Results showed that there was an excessive leakage in the İçmeler network, especially in winter. Seasonal trends of leakage levels and total water consumption were similar to Armutalan. As there is a strong relationship between pressure and leakage, the network was recommended to be operated between 3 and 4 bars. Nevertheless, most of the storage tanks, which served the treated water to the network, were located in an elevation strip between 75 and $85 \mathrm{~m}$. A substantial portion of the city supplied by these storage tanks was located between 0 and $25 \mathrm{~m}$. 
As a result, this large area was operated with pressures between 5 - 7 bars. Also, the buildings located in the region had a single or double flat. Thus, pressures were unnecessarily high in the network and should be reduced to 2-3 bars (20-30 $\mathrm{mWC})$. High-pressure causes leakage, bursting, and some of the used pipe types (Asbestos Cement (AC) and Polyvinyl Chloride (PVC)) increased leaking and bursting problems under the high pressure in the network. Breakdown records supported that by showing the most frequently encountered problem was the network line bursts, especially for the small diameters (100 and $150 \mathrm{~mm})$ AC pipes. High pressures could be reduced by the pressure reducing valves installed in the network. Outlet pipes and tanks could be operated with full flows, and inappropriate pipes should be replaced with more durable pipes. Nevertheless, network models should be calibrated and more manageable district metered areas (DMAs) could be established to reduce physical losses during the planning phase of the project following the results of this feasibility study. Another suggestion would be the extension of the repair team works to control physical losses for quicker response and less tight schedule.

\section{Efficiency indexes and ratios.}

The efficiency indexes, ratios, and technical performance category of the municipal water system in the study area were determined as follows:

- The water production ratio was $99.5 \%$, which was obtained from the flow rates measures in the inlet and the outlet of the water treatment plant, and this ratio shows the good performance of the facility.

- Non-Revenue Water (NRW) ratio was $42.7 \%$ and the determined NRW technical performance category was $\mathrm{C}$ (poor NRW record; tolerable only if the water is plentiful and cheap; even then, analyze level and causes of $N R W$ and intensify NRW reduction efforts).

- Physical Losses ratio was $28.9 \%$ and the performance category was C (similar to NRW).

- The administrative losses ratio was $8.7 \%$ and it was higher than the desirable rate for both unauthorized unbilled (illegal) consumption (5\%) and metering \& billing errors (6\%). ILI value was estimated as 5.16 by dividing CARL (11,238,805 lt/day) with UARL (2,178,020 1t/day). UARL calculated by the use of the following information: Lm: $250 \mathrm{~km}$; Nc: 30,286; Lp: $302.9 \mathrm{~km}$; and P: $60 \mathrm{mWC}$. The calculated ILI corresponded with the Category $\mathrm{C}$.

NRW, physical loss, administrative loss, and ILI ratios showed that actions need to be taken for increasing water efficiency in the network. 


\section{Model Results}

A hydraulic model was used to understand the current status of the water distribution network and any potential effects of the applied practices and measures (e.g., adding new valves, changing pipes, flow rate, and pressure control, establishing DMAs and PMAs). This model includes several elements such as pump stations, storage tanks, water demands, the layout of the area, and other present hydraulic devices.

\section{Water quantity modeling.}

In Marmaris, one of the most important matters is high physical losses in the network. The major reason for the physical losses in the system was because of high pressure in the network, especially in winter times. Thus, the high-pressure problem should be eradicated. Water loss status projections considering both "without" and "with" scenarios are shown in Figure 7. The water loss projection results indicate that the expected reduction in water loss needs actions for water efficiency improvements. As a result of applying measures, the total water losses with a value in 2018 of $37.6 \%$ would decrease to $24.6 \%$ in 2023 (19.9\% Physical Losses and $4.8 \%$ Administrative Losses) and would reach a value in 2038 of $20.3 \%$ (18.0\% Physical Losses and 2.3\% Administrative Losses).

Water demands and the ability of the water supply network to meet the rising demands were calculated for with-project and without-project scenarios. In order to observe the responses of the system to changing demands during a certain period of time, a dynamic analysis needs to be performed. In WaterCAD, it is named Extended Period Simulation (EPS). Total water demand depicted the same trend in 2018 with $14,184,650 \mathrm{~m}^{3}$, and it would be $22,204,429 \mathrm{~m}^{3}$ in the without-project scenario in 2038, while it would be 19,852,469 $\mathrm{m}^{3}$ in the with-project scenario (Figure 8).

The present water supply system would not be able to provide sufficient demands in 2038 in certain locations after establishing the DMAs and PMAs. Main and primary pipelines in the Marmaris were oversized; the replacement of the pipes and changing the pipe dimensions were not necessarily required. The topography of the study area is flat, and there are mostly low elevations in this area. Hence, it has positive impacts on the future performance of the system. On the other side, it was not possible to create DMAs and PMAs without pipe replacement within the current pipelines and the topography. To illustrate, a ring line was required to supply water to isolated areas with higher elevations in Armutalan. After improvements in this study, water would significantly reach more locations. 
According to the information provided by the regional personnel of MUSKI, small diameter (100 and $150 \mathrm{~mm}$ ) AC pipes are problematic and they can frequently burst. These pipes substantially exist in the Marmaris network, and this existence is reflected in the burst records. Therefore, small diameter AC network pipes have been proposed to be replaced in the scope of the rehabilitation works. Replacement of 9,807 m of AC lines with Ductile Iron pipes, new lines that will be laid for DMA establishment, and 1,100 consumer connections are anticipated to improve the efficiency in the water supply network.

\section{District metered areas (DMAs).}

21 DMAs were established in the study area (8 in Marmaris, 7 in Armutalan, 4 in İçmeler, and 2 in Beldibi). The DMAs were established by closing the existing valves on the DMA boundaries and adding new valves on the boundary pipes which do not have isolation valves. The DMAs can also be established by placing dead ends to the boundary pipes rather than ensuring isolation by valves. This brings the advantage of providing isolation of the area to ease the management of the water leakages. Figure 9 shows the proposed DMAs and PMAs in the project area.

\section{Figure 7}

Water Loss Status Projections

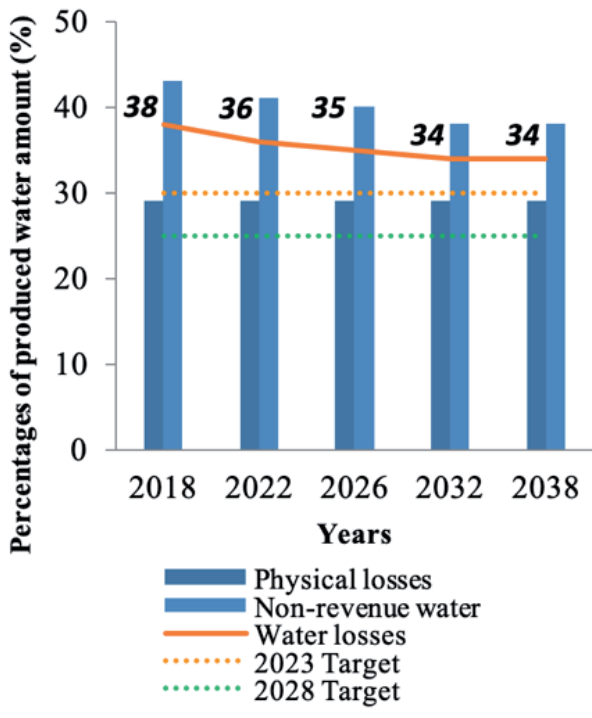

(a) "Without Project" scenario

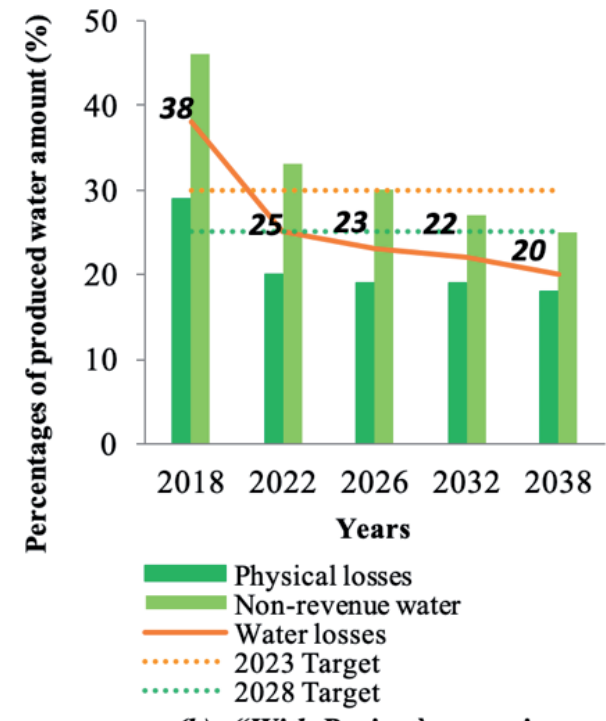

(b) "With Project" scenario 


\section{Figure 8}

Water Demand Projections

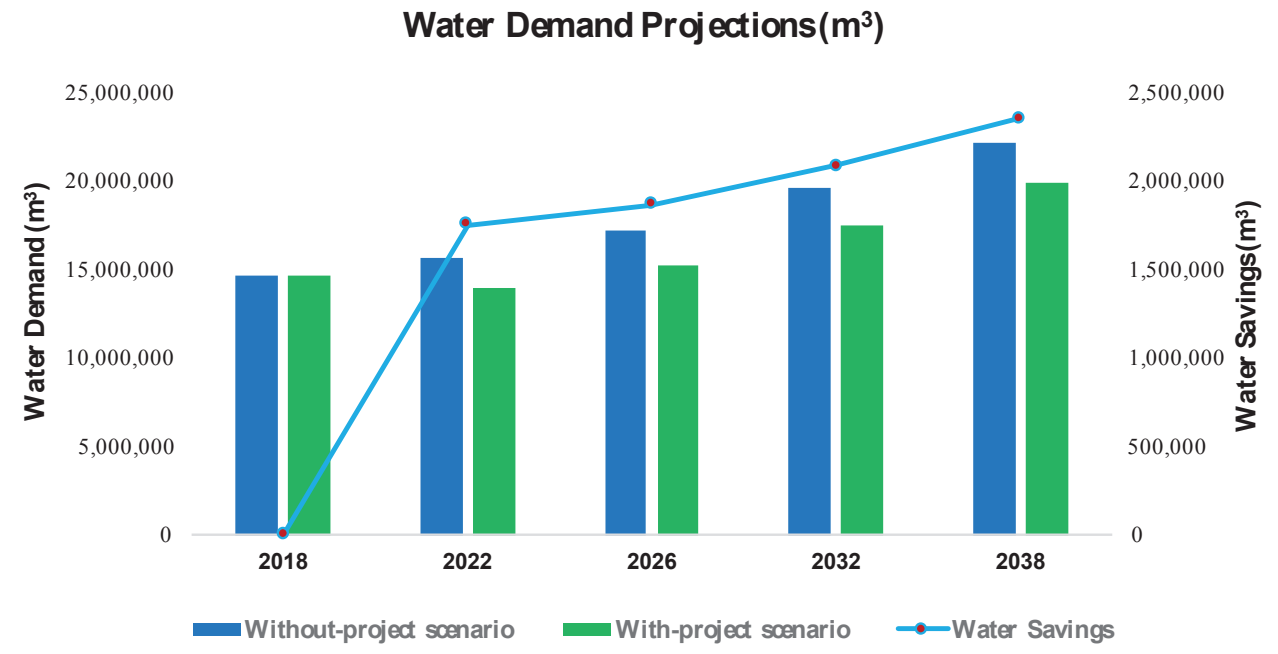

\section{Pressure management areas (PMAs).}

11 PMAs were created for pressure reduction in the study area. The established PMAs can be found in Figure 9 (boundaries shown by thick full continuous lines). PMA-M1 is the main PMA of the network that was created by adding 2 pressure-reducing valves (PRV) on the main pipelines. There are various DMAs within the boundary of this PMA. The second one was established by installing a pressure reducing valve (PRV-M3) on the main pipe at the north of the Marmaris-Datça highway. There are five PMAs established for the network in Armutalan in addition to the Marmaris network. All of the PMAs in there is also a DMA. The PMAs in Armutalan have similarities with the ones in İçeler, where the physical loss ratio during winter is as high as $70 \%$. PRVs were implemented to reduce the upstream pressure to a set value, regardless of its magnitude. Besides, the installed PRVs should be controlled remotely by the SCADA. PRVs can be taken into operating status during the nights while there may be no need for pressure reductions during day time because of the high consumption. Operational flexibility would ensure both the highest level of service and efficiency in water use at the same time. The comparison of storage tank outflows with and without pressure management can be seen in the appendix based on 2018 winter scenario (Figure A1). 
As a result, the number of proposed flow meter chambers and PRV chambers in the network of the study area as follows: 8 flow meter chambers, 3 PRV chambers in Marmaris; 7 flow meter chambers, 5 PRV chambers in Armutalan; 2 flow meter chambers, 1 PRV chamber in Beldibi; 4 flow meter chambers, 3 PRV chambers in İçmeler.

\section{Figure 9}

\section{Proposed DMAs and PMAs in Marmaris}

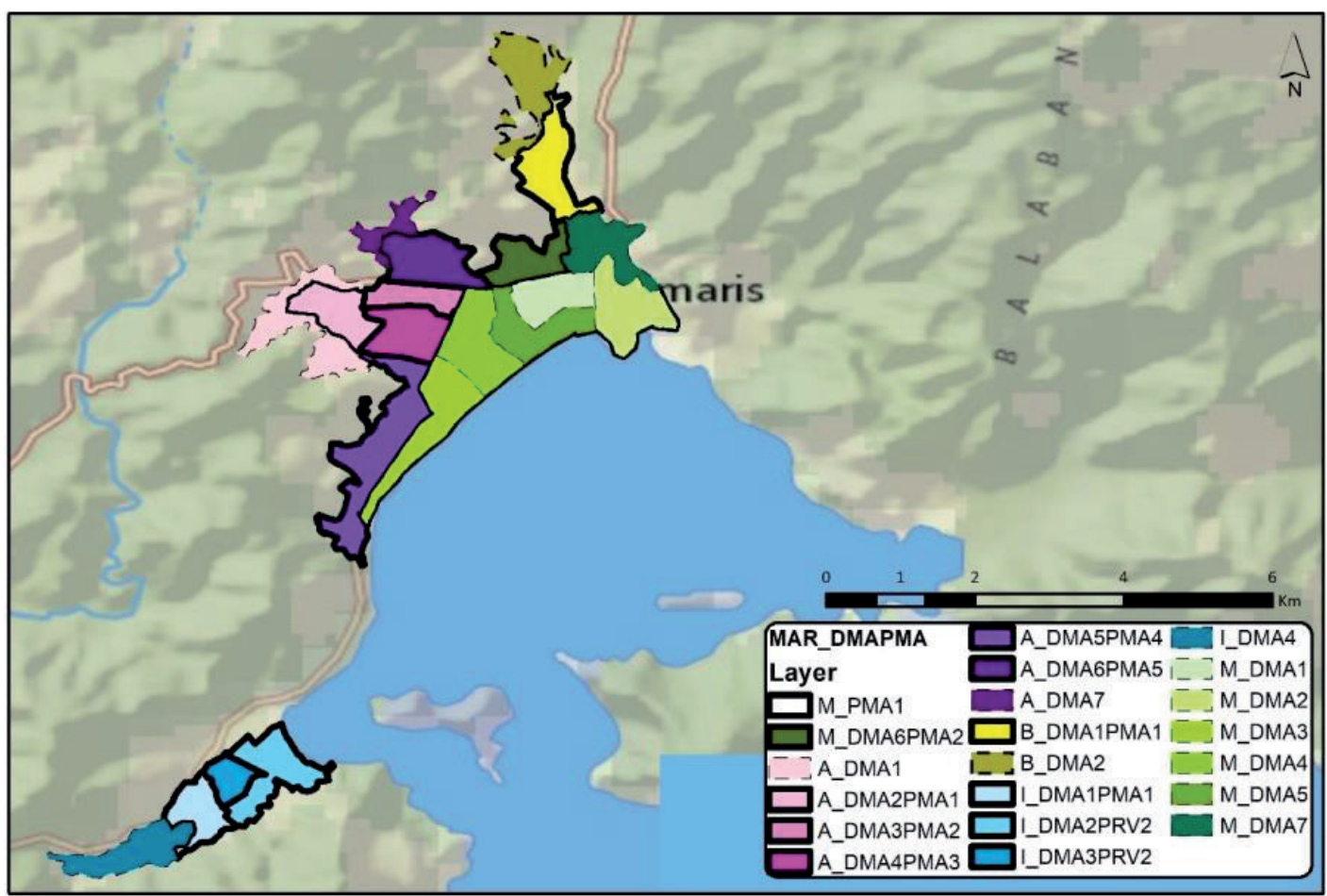

\section{Water quality modeling.}

Water quality analyses were conducted in the model after the establishment of DMAs and PMAs, which affect the route of water due to isolation. Two major quality parameters were analyzed with the demand of the 2018 winter: water age, residual chlorine.

Water age in the network at the beginning was set as 0, and the Extended Period Simulation (EPS) model was run for a long period (168 hours). Beldibi pressure zone always receives freshwater as the area is the inlet point after the 
DWTP. In addition to this, the water age was relatively older in the Marmaris and Armutalan networks. In İçmeler, water consumption was low; therefore, the water stays in the pipeline longer. Figure 10-a illustrates the age of water in pipes at the $168^{\text {th }}$ hour of the hydraulic model. Figure 10 -a shows that there were water age problems in the DMAs. It is advised to implement periodic isolation valve opening and closing exercises on boundary valves or flushing activities via fire hydrants following the completion of the investments.

Residual chlorine concentrations in the network were also simulated to estimate chlorine concentrations in the system. Chlorine-water (bulk reaction) and chlorine-pipe (wall reaction) interactions are assumed to be covered by a single, linear reaction function, $\mathrm{r}=\mathrm{kCn}$; where $\mathrm{r}$ is the rate of reaction (mass/volume/time), $\mathrm{k}$ is the reaction constant (concentration raised to the power of [1-n] divided by time), $\mathrm{C}$ is the reactant concentration (mass/volume), and $\mathrm{n}$ is the reaction order. As the linear approach assumes $\mathrm{n}$ equals 1 , the reaction equation could be simplified to $\mathrm{r}=$ $\mathrm{kC}$. Chemical parameters of chlorine have been taken as $1.44 \mathrm{e}-9 \mathrm{~m}^{2} / \mathrm{s}$ for diffusivity and $-1.00 \mathrm{mg} / \mathrm{l}(1-\mathrm{n} /$ day $)$ for bulk reaction, where wall reaction is assumed to be also included. As a linear model is adopted for bulk reaction (i.e., $\mathrm{n}=1$ ), the bulk reaction rate used in the model has become -1.00 day $^{-1}$. The chlorine analysis results have shown that the residual chlorine amount in Marmaris and Armutalan regions was in the desirable range (0.2-0.5 mg/L). However, in İçmeler, Adaköy, and Gökbel regions, there were low water consumption and so lower water velocity in pipelines; therefore, estimated residual chlorine amounts reduced below the minimum value in regulations $(<0.2 \mathrm{mg} / \mathrm{L})$. The amount of chlorine dosage was set as $0.8 \mathrm{mg} / \mathrm{l}$ in the DWTP to put up with spreading in the storage tank in Beldibi and transmission line. Hence, the residual chlorine amounts in Beldibi did not slightly meet the upper limit concentration in the by-law of the Ministry of Health Regulation concerning Water Intended for Human Consumption $(0.5 \mathrm{mg} / \mathrm{l})$ (Official Gazette of the Republic of Turkey, 2013). Figure 10-b shows the residual chlorine analysis results. As the hydraulic model was not calibrated for chlorine analysis, the proposal of certain remedies is not reasonable at this stage of the study. It is recommended to monitor the amount of chlorine in critical locations. Additionally, an extra chlorination system might be added to the İçmeler storage tank according to the observations.

Following the completion of the investments, MUSKI is recommended to calibrate the hydraulic model by means of the comprehensive SCADA instrumentation. Besides, the numbers of site tests at each of the DMAs are recommended to be done. It is known that models are calibrated more accurately under high flow conditions such as hydrant openings. Therefore, while calibrating a DMA, more than one field test should be performed at several hydrants. In addition, 
the selection of hydrants apart from the flow meter chamber increases the accuracy of the calibration.

\section{SCADA Assessment}

The SCADA system should include new control stations within the DMAs and PMAs to increase water use efficiency, prevent water supply failures, and decrease water losses. The recommended new control stations should cover the monitoring of the residual chlorine, flow rates, network pressure.

The current status of the SCADA system was projected to be improved by having several upgrades, for instance, a more decent communication network through Very Small Aperture Terminal (VSAT) satellite terminals, increased electrical autonomy of the control stations by the use of larger Uninterruptible Power Supply (UPS) to avoid dataflow issues during electrical deficiencies, and more apparatus in the current control stations such as flow meters, pressure transmitters, level meters, and the position detection for valves. For this reason, recently available technologies for the extension of the current SCADA system were taken into account to have more reliable, resilient, scalable, and functional systems without jeopardizing the present performance of the system. The main functions to be performed, proposed measures and necessary extensions for the SCADA system can be seen in Figure 11.

\section{Figure 10}

Water Age Analysis Results (A) and Residual Chlorine Analysis Results (B)
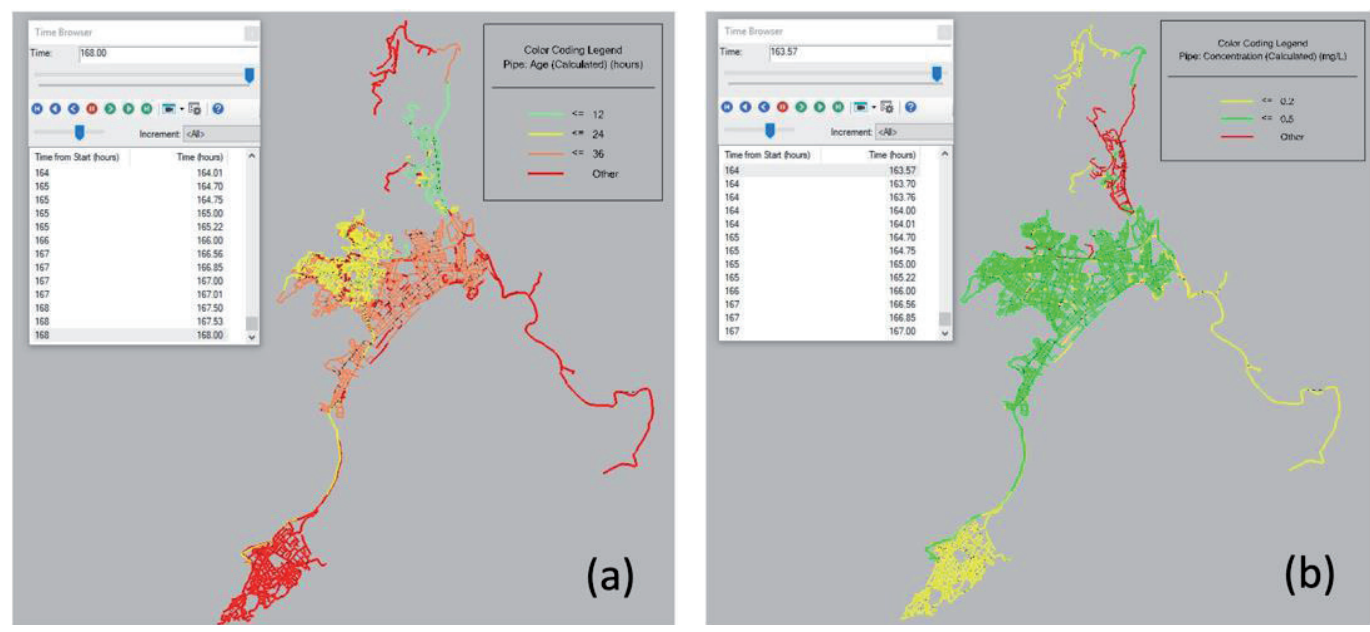
These given functions should be accessed remotely from the control center; additionally, operators in the field should be able to control the system through the Human Machine Interface (HMI) interface on the control panels. They should be controlled not only manually but also automatically by Remote Terminal Unit (RTU) and/or by the central SCADA system. These operation modes (local, remote, and automatic) should be applicable at various control stations and control centers.

The new proposed extension of the current SCADA system for smoothly running, problem-free controlling, and monitoring the network should depend on standard software and hardware. Besides, it should be able to integrate with the current SCADA system. The configured system should also be able to extend further according to future necessities.

To achieve better water management within the urban distribution network, new control stations should be built and included in the SCADA system. These new control stations are mainly required for the DMAs and PMAs. Different types of control stations should be implemented for pressure and flow metering in the DMAs and PMAs. Therefore, new control panels with RTUs, GSM/GPRS communication modems, the correspondent instrumentation, and control valves should be installed inside the underground chambers built for these purposes. The proposed new control stations are as follows: 21 flow and 21 pressure metering stations, 12 pressure control stations, 4 chlorine monitoring stations.

\section{Cost-Benefit/Unitary Price Analyses}

Cash flows were calculated by subtracting the total revenues from the total costs for with- and without-project scenarios from the beginning year of the project (2018) till the final year (2038) of the planning cycles. The with-project scenario includes the investments of the measures taken under the scenario.

First, the current prices for 2018 were calculated, then constant prices have been estimated by applying a discount rate of $10 \%$ (Winpenny, 2005). Figure 12 illustrates the Cost-Benefit Analysis (CBA) for the selected scenarios in the study. 
Mehmet Can Güçlü, Burak Ekinci, Aslıhan Korkmaz, Yusuf Başaran, Yakup Karaaslan,

Serdar Aldemir, Ayhan Türkoğlu, Ali Serindăg, Jose Alberto Colino Fernandez, Kerem Ar, Baki Ülgen, Bilal Dikmen, Bekir Pakdemirli

Turkish Journal of Water Science \& Management 5 (1) (2021) / 2 - 39

\section{Figure 11}

The Main Functions to be Performed by the Enhanced SCADA System (a) and Proposed Extensions for the Current System (b)

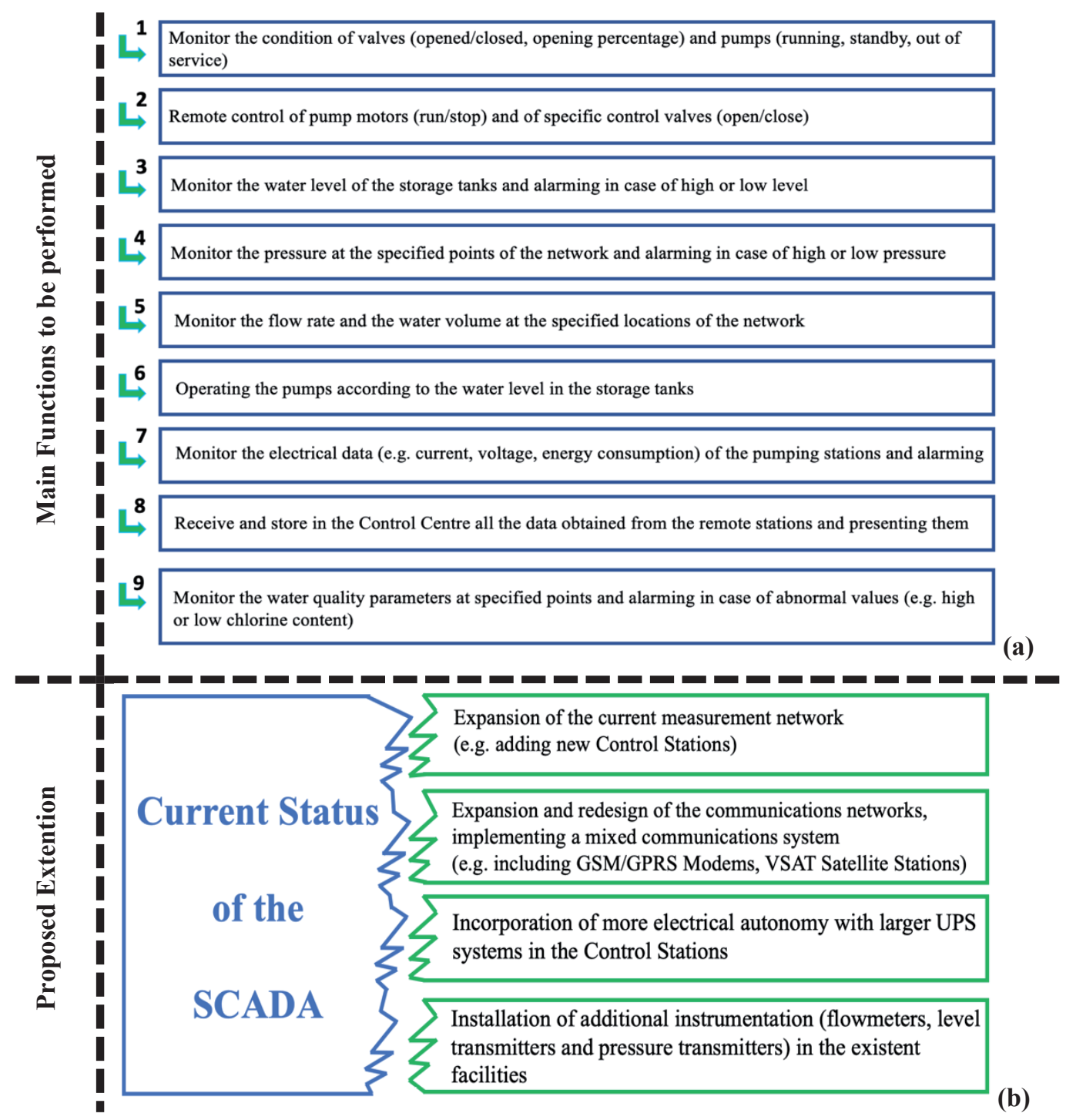




\section{Figure 12}

Cost/Benefit Balance for Without-Project and With-Project (Constant Prices)

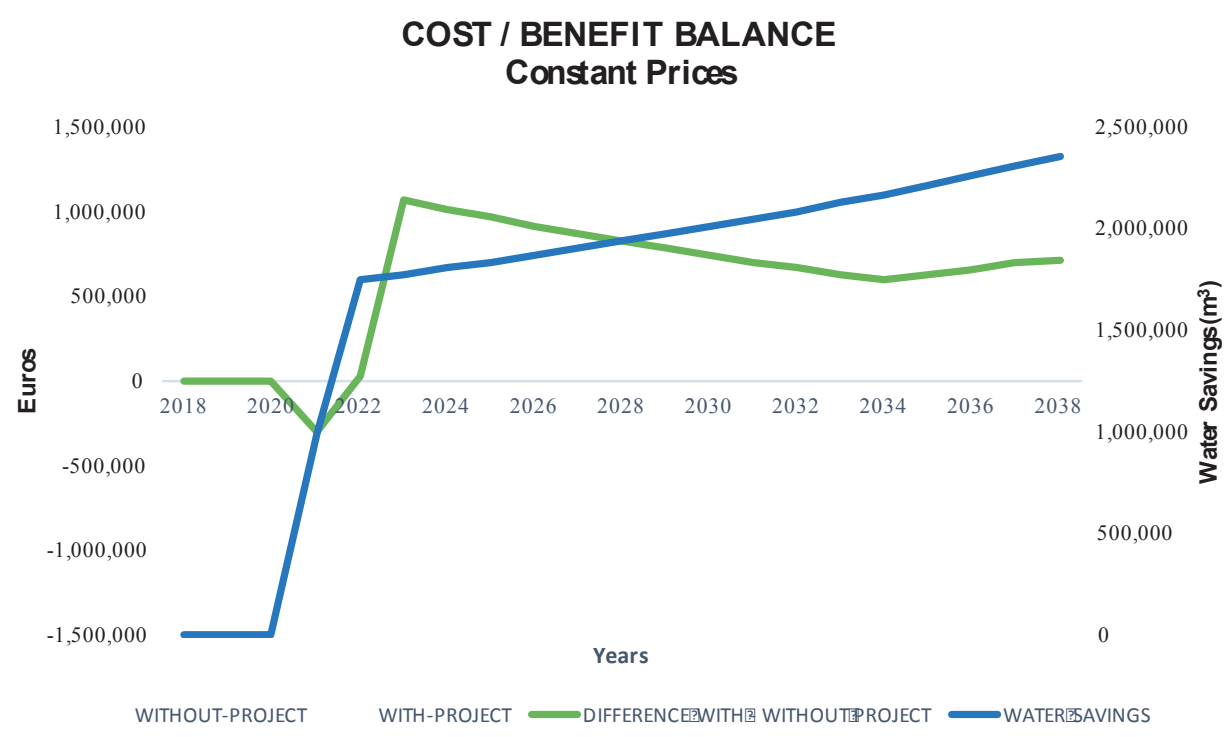

Figure 12 shows that the cash flows during the first 3 years $(2018,2019$, and 2020) are the same, and the with-project scenario shows a decreasing trend between 2021 and 2022. Investments are expected to be carried out to increase water use efficiency between 2021 and 2022; therefore, cash flow changes are not expected before. The negative income of the investment costs would be during the investment period. For the with-project scenario, an increase in the cash flows is higher than the without-project scenario. After 2023, cash flows are positive in the with-project scenario; on the other hand, they are projected to be positive after 2029 in the without-project scenario. The difference in the gap between the two scenarios starts to be the largest just after the investment, then closing down steadily, and starting to be increased slightly from 2034 to 2038 . Consequently, it is inevitable that the cash flows of the investments with-project scenario are financially positive and beneficial for the study area. The CBA depicted negative values regarding the Net Present Value (NPV) with the without-project scenario while the NPV was positive with the project. Internal Rate of Return (IRR) was estimated as $1 \%$ without the project and $14 \%$ with the project. The investment's payback period was estimated as 5.5 years (2027) and the payback period with a 10\% discount applied was 6.8 years (2028). Finally, the abovementioned results clearly show that this project can be implemented. 
The implementation of the proposed measures has a crucial impact on the water loss decrease, and the water demand in the system would reduce. Hence, the costs of water transmission and treatment would decrease, while the unitary price as well. The unitary cost of the water supply can be calculated by consisting of the cost of the water and wastewater utilization. In this study, two approaches were used to calculate the unitary cost. The first approach was the consideration of the investment to be conducted as planned in 2021 and 2022. The second approach was the consideration of the total investment shared among the total life cycle of the project from 2021 to 2038 . It was found that the unitary prices vary between $\mathbf{1 . 3 1} \mathbf{\epsilon} / \mathbf{m}^{\mathbf{3}}$ and $1.21 € / \mathrm{m}^{3}$ for the without- project scenario and between $1.31 € / \mathrm{m}^{3}$ and $1.00 € / \mathrm{m}^{3}$ for the with-project scenario in the first approach. The second approach showed that the unitary price values for the with-project scenario decrease moderately from $\mathbf{1 . 3 1}$ $\boldsymbol{€} / \mathbf{m}^{3}$ to $\mathbf{1 . 0 2} € / \mathbf{m}^{\mathbf{3}}$ while the without-project scenario remained the same because there are not any proposed measures. The reduction of water losses after rehabilitation was projected to be nearly $13 \%$ compared to the without-project scenario in 2038. Figure 13 compares the total water losses and unitary price of the water system along the project cycle from 2018 to 2038.

\section{Figure 13}

Water Losses \& Water Unitary Price for Without-Project-With-Project Scenarios for 2021-2022 and 2021-2038

Water Losses \& Water Unitary Price

(Investment: 2021-2022 \& 2021-2038)

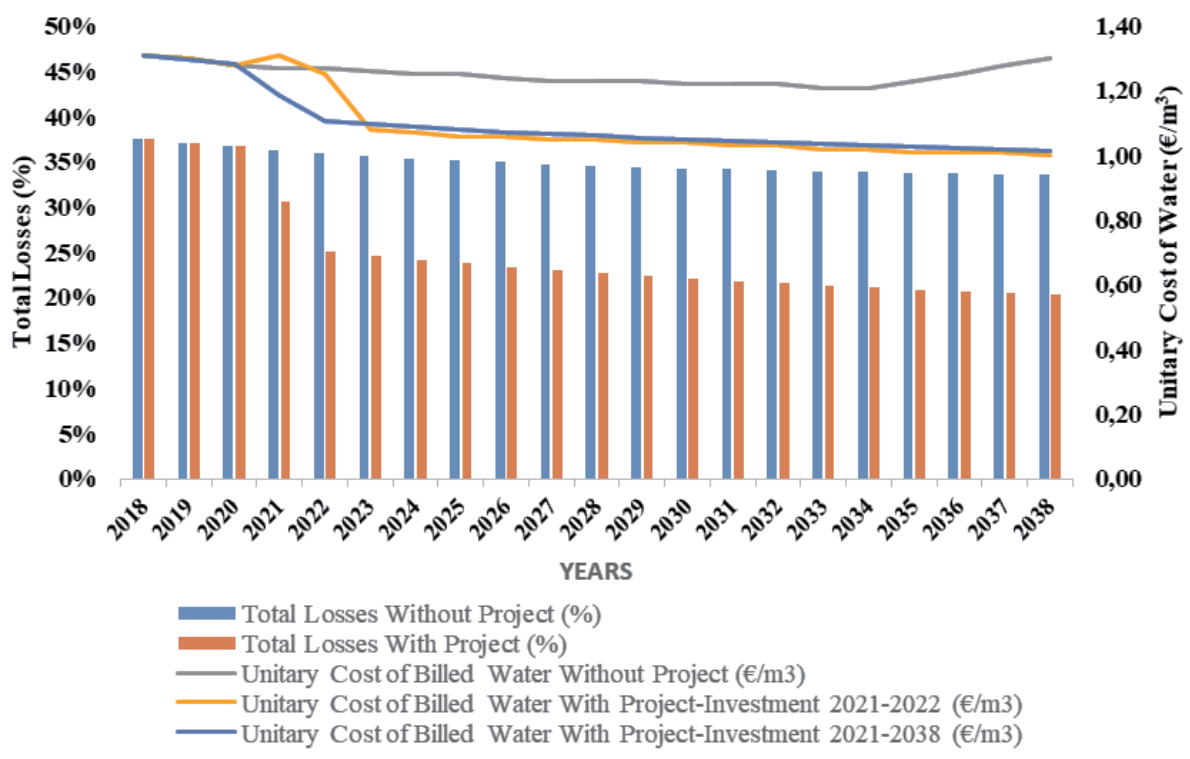




\section{Other Complementary Measures}

In the previous chapters, the described actions were mainly in accordance with the physical loss decreases. This section describes other complementary measures to improve management practices of the water system as follows: 1) Administrative Losses Reduction Plan, 2) Personnel Capacity Building Plan, 3) Public water saving awareness campaigns, 4) Tariff related measures.

Regarding the Administrative Losses Reduction Plan, administrative losses (apparent losses) are one of the necessary elements for water loss control. The administrative losses have two major components: meter reading failures/billing errors and unauthorized illegal consumption. Two major activities could be applied to deal with those problems: integrated customer water management and regularizations of the illegal connections.

Personnel Capacity Building Plan is a well-known conception and strategy to improve the sustainability of the water services at various levels (i.e., sectoral, institutional, and individual). It is an ongoing measure within all the activities taken place in the water sector. It also requires the implementation of several certain methods to improve sectoral productivity and so better practices in sectoral abilities. All these skills can be developed by the application of Capacity Building Plans (CBPs) including the major topics regarding the efficient use of water and better management practices. This measure should be carried out at the provincial level (not only at the district level) because of the organizational structure of the water and sewerage administration, which has to be homogenous throughout the water system staff within the consideration of the full institution.

Public water saving awareness campaigns contribute to the development of awareness at the full degree of individuals regarding the significance of the watersaving to deal with water shortages and provide sustainability in the future. It aims to increase individuals' behaviors for increasing water use efficiency. They can be implemented by giving education and awareness campaigns within the consideration of the environmental and socio-economic advantages of water-saving. This measure should be implemented not only at the district level but also at the provincial level being MUSKI managerial organization.

Tariff related measures are one of the complementary measures proposed in this study. Progressive pricing is a tool that can be used to administer water demand and support the reduction of extreme water consumption through an economic disincentive. It can be implemented by increasing water price rates in parallel with increased water consumption volumes. Hence, individuals who consume the largest 
amount of water would pay more beyond a specific threshold, which is generally determined by the average water demands of certain subscribers. Besides, the waterworks department may use some of the pricing analyses (e.g., affordability of the households, willingness to pay) in addition to the territorial water consumption trends when identifying the pricing blocks. Effective progressive pricing can also be monitored by establishing water conversation objectives and revenue goals. Pricing planning should also include public engagement via advertisements and meetings to inform individuals. It may cover key points about the water conversation and prevention of water consumption along with the advantages of progressive pricing. Since the tariff setting has been implemented at the level of metropolitan municipality, certain measures are not possible to apply at the district level.

\section{Conclusion and Recommendations}

This study concentrates on the efficiency aspects of the Marmaris water supply system. WaterCAD model was used as an analytical tool to simulate proposed measures in this study. Initially, for instance, pressure reduction valves are proposed to be installed to control high pressures in the network. Besides, DMAs to control leakages and PMAs to monitor high pressures should be established in the network. Infrastructures could be rehabilitated as well to control high pressures in the system. After the model runs, 21 DMAs and 11 PMAs were recommended in this study. The rehabilitation of the infrastructure could also cover the rebuilding and/or extension of the network with other elements (e.g., valves, meters, etc.). The modeling study was performed for this feasibility study; therefore, it is highly recommended to conduct more calibration tests when the investment is decided to be done. In addition to this, on-site tests are advised to carry out in each DMA; for example, hydrant openings can be used for the calibration due to the high flow status, which ensures more accurate calibration. Hence, several field tests should be implemented at different hydrants when a DMA is calibrated. Hydrant beyond the flow meters can also be selected to increase the quality of the calibration. When the investments are finalized, the calibration of the hydraulic model is highly advised by using the SCADA media. The system should also be enhanced by dealing with illegal consumption, metering inaccuracies/reading, and billing failures. Nevertheless, the current SCADA system could be improved since it only provides limited control of the system without remote control of the particular equipment. Last but not least, some complementary measures were identified to increase efficiency in the municipal water sector. After the implementation of the investments, gross water consumption per capita is expected to be $411 \mathrm{lcd}$ in 2035 . On the other hand, it is estimated to be 470 lcd for the without-project scenario. Water subscribers in the network would have less water compared to their demand without the project in 
2035; therefore, results show that investments ensure adequate water supply in the future.

The Cost-Benefit analysis depicted negative values regarding the Net Present Value (NPV) with the without-project scenario while the NPV was positive with the project. Internal Rate of Return (IRR) was estimated as $1 \%$ without the project and $14 \%$ with the project. The investment's payback period was estimated at 5.5 years (2027) and the payback period with a 10\% discount was 6.8 years (2028). The total cost of the investment was calculated as $\boldsymbol{€ 2 , 9 5 6 , 7 3 9 . 2 6}$ to be implemented during the years 2021 and 2022. The analysis of the unitary prices showed that they vary between $\mathbf{1 . 3 1} € / \mathrm{m}^{3}$ and $\mathbf{1 . 2 1} € / \mathrm{m}^{\mathbf{3}}$ for the without- project scenario and between $\mathbf{1 . 3 1}$ $\boldsymbol{€} / \mathbf{m}^{3}$ and $\mathbf{1 . 0 0} € / \mathbf{m}^{3}$ for the scenario with-project.

In both cases, the decrease in the unitary price of water for the with-project scenario is more beneficial than the without-project scenario; therefore, implementation of the proposed investments is recommendable. We point out some recommendations to increase the efficiency in the municipal sector for future studies:

- The preparation of the water balance table should be done with higher precision to control the system more efficiently in a broader picture.

- Hydraulic models could be used as an analytical tool to understand complex water system conditions such as water distribution networks, and taking actions for improvements on the system.

- SCADA should be implemented to monitor and control a system and to calibrate the model remotely.

- Water authorities should perform active leak detection studies, and several teams should be formed for continuous leak detection.

- Implementation of the abovementioned complementary measures should be considered.

- An integrated assessment would be fruitful to conduct a more detailed system analysis holistically. A life cycle assessment can be applied together with hydraulic modeling, financial, and social analyses; thus, sustainability aspects would bring resilience to future circumstances.

\section{Acknowledgment}

This study is based on the European Union co-financing project titled "Technical Assistance on Economic Analyses within River Basin Management Plans and Water Efficiency Aspects in 3 Pilot River Basins in Turkey, Contract No. TR2013/0327.07.01-01/001 (2017-2021)" within the activity of the municipal sector feasibility study on water efficiency. 


\section{References}

Awe, O. M., Okolie, S. T. A., \& Fayomi, O. S. I. (2019). Review of water distribution systems modelling and performance analysis softwares. Journal of Physics: Conference Series, 1378. DOI:10.1088/1742-6596/1378/2/022067

Gomes, R., Sousa, J., Muranho, J., \& Marques, A. S. (2015). Different design criteria for district metered areas in water distribution networks. Procedia Engineering, 119, 1221-1230. https://doi.org/10.1016/j.proeng.2015.08.981

Karadirek, I. E., Kara, S., Yilmaz, G., Muhammetoglu, A., \& Muhammetoglu, H. (2012). Implementation of hydraulic modelling for water-loss reduction through pressure management. Water Resources Management, 26, 2555-2568. DOI: 10.1007/s11269-012-0032-2

Khadam, M. A., Shammas, N. K., \& Al-Feraiheedi, Y. (1991). Water losses from municipal utilities and their impacts. Water International, 16(4), 254-261. https://doi.org/10.1080/02508069108686121

Kummu, M., Guillaume, J. H., de Moel, H., Eisner, S., Flörke, M., Porkka, M., Siebert, S., Veldkamp, T.I.E., \& Ward, P. J. (2016). The world's road to water scarcity: shortage and stress in the 20th century and pathways towards sustainability. Scientific Reports, 6, 38495. DOI: 10.1038/srep38495

Lambert, A., Brown, T., Takizawa, M., \& Weimer, D. (1999). Review of Performance Indicators for Real Losses from Water Supply Systems. J. Water SRT-AQUA, 48, 227-237.

Liemberger, R., \& McKenzie, R. (2005). Accuracy Limitations of the ILI: Is It an Appropriate Indicator for Developing Countries? IWA Leakage Conference; 12-14 September 2005. Halifax, Canada.

Liemberger, R. (2010). Recommendations for initial non-revenue water assessment. IWA Water Loss.

Muhammetoglu, A., Muhammetoglu, H., Adiguzel, A., Iritas, Ö., \& Karaaslan, Y. (2018). Management of water losses in water supply and distribution networks in Turkey. Turkish Journal of Water Science \& Management, 2(1), 58-75. https://doi.org/10.31807/tjwsm.354298

Official Gazette of the Republic of Turkey. (2013). Turkish Ministry of Health Regulation Concerning Water Intended for Human Consumption. Official gazette dated 07/03/2013 and numbered 28580, Ankara, Turkey.

Official Gazette of the Republic of Turkey. (2014). By-Law regarding the Control of Water Losses in Drinking Water Supply and Distribution Systems. Official gazette dated 08/05/2014 and numbered 28994, Ankara, Turkey.

Official Gazette of the Republic of Turkey. (2019). Amending by-law on the by-law regarding Control of Water- Losses in Drinking Water Supply and Distribution Systems. Official gazette dated 31/08/2019 and numbered 30874, Ankara, Turkey.

Puust, R., Kapelan, Z., Savic, D. A., \& Koppel, T. (2010). A review of methods for leakage management in pipe networks. Urban Water Journal, 7(1), 25-45. https://doi.org/10.1080/15730621003610878 
Renzetti, S., \& Dupont, D. P. (2013). Buried treasure: the economics of leak detection and water loss prevention in Ontario. Rep. No. ESRC-2013, 1. Retrieved May 15, 2020 from https://core.ac.uk/download/pdf/62644197.pdf

Terlumun, U. J., \& Robert, E. O. (2019). Evaluation of municipal water distribution network using waterCAD and waterGEMS. Kastamonu University Journal of Engineering and Sciences. 5(2):147-156.

Winpenny, J. (2005). Guide to Investment Appraisal for DFID Economists. Retrieved October 19, 2020, from https://assets.publishing.service.gov.uk/media/57a08ca140f0b6497400132c/ IA_Guide.pdf

WSD-Water Loss Management. (n.d.). Retrieved July 10, 2020, from https://www.wsd.gov.hk/en/core-businesses/operation-and-maintenance-ofwaterworks/reliable-distribution-network/index.html 


\section{Appendix}

\section{Table A1}

International NRW Assessment Matrix (Liemberger, 2010)

\begin{tabular}{|c|c|c|c|c|c|c|}
\hline \multicolumn{7}{|c|}{ International NRW Assessment Matrix } \\
\hline \multirow{2}{*}{\multicolumn{2}{|c|}{$\begin{array}{r}\text { Technical } \\
\text { Performance } \\
\text { Category } \\
\end{array}$}} & \multicolumn{5}{|c|}{$\begin{array}{l}\text { NRW (Liters/connection/day) } \\
\text { When the system is pressurized at an average pressure of: }\end{array}$} \\
\hline & & $10 \mathrm{~m}$ & $20 \mathrm{~m}$ & $30 \mathrm{~m}$ & $40 \mathrm{~m}$ & $\geq 50 \mathrm{~m}$ \\
\hline \multirow{5}{*}{ 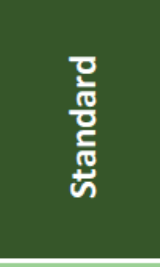 } & A1 & & $<50$ & $<65$ & $<75$ & $<85$ \\
\hline & A2 & & $50-100$ & $65-125$ & 75-150 & 85-175 \\
\hline & B & & $100-200$ & $125-250$ & $150-300$ & $175-350$ \\
\hline & C & & $200-350$ & $250-450$ & $300-550$ & $350-650$ \\
\hline & D & & $>\mathbf{3 5 0}$ & $>450$ & $>\mathbf{5 5 0}$ & $>650$ \\
\hline \multirow{5}{*}{ 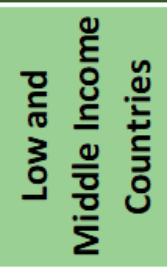 } & A1 & $<55$ & $<80$ & $<105$ & $<130$ & $<155$ \\
\hline & A2 & $55-110$ & $80-160$ & $105-210$ & $130-260$ & $155-310$ \\
\hline & B & $110-220$ & $160-320$ & $210-420$ & $260-520$ & $310-620$ \\
\hline & C & $220-400$ & $320-600$ & $420-800$ & $520-1000$ & $620-1200$ \\
\hline & D & $>400$ & $>600$ & $>800$ & $>1000$ & $>1200$ \\
\hline
\end{tabular}




\section{Table A2}

International Physical Loss Assessment Matrix (Liemberger \& McKenzie, 2005; Liemberger, 2010)

\begin{tabular}{|c|c|c|c|c|c|c|c|}
\hline \multicolumn{8}{|c|}{ Physical Loss Assessment Matrix } \\
\hline \multirow{2}{*}{\multicolumn{2}{|c|}{$\begin{array}{r}\text { Technical } \\
\text { Performance } \\
\text { Category } \\
\end{array}$}} & \multirow[t]{2}{*}{ ILI } & \multicolumn{5}{|c|}{$\begin{array}{l}\text { Physical Loss (Liters/connection/day) } \\
\text { When the system is pressurized at an average pressure of: }\end{array}$} \\
\hline & & & $10 \mathrm{~m}$ & $20 \mathrm{~m}$ & $30 \mathrm{~m}$ & $40 \mathrm{~m}$ & $\geq 50 \mathrm{~m}$ \\
\hline \multirow{5}{*}{ 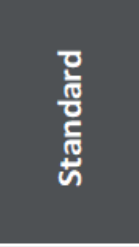 } & A1 & $<1.5$ & & $<25$ & $<40$ & $<50$ & $<60$ \\
\hline & A2 & $1.5-2$ & & $25-50$ & $40-75$ & $50-100$ & $60-125$ \\
\hline & B & $2-4$ & & $50-100$ & $75-150$ & $100-200$ & $125-250$ \\
\hline & C & $4-8$ & & $100-200$ & $150-300$ & $200-400$ & $250-500$ \\
\hline & D & $>8$ & & $>200$ & $>300$ & $>400$ & $>500$ \\
\hline \multirow{5}{*}{ 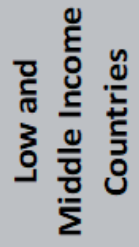 } & A1 & $<2$ & $<25$ & $<50$ & $<75$ & $<100$ & $<125$ \\
\hline & A2 & $2-4$ & $25-50$ & $50-100$ & $75-150$ & $100-200$ & $125-250$ \\
\hline & B & $4-8$ & $50-100$ & $100-200$ & $150-300$ & $200-400$ & $250-500$ \\
\hline & C & $8-16$ & $100-200$ & $200-400$ & $300-600$ & $400-800$ & $500-1000$ \\
\hline & D & $>16$ & $>200$ & $>400$ & $>600$ & $>800$ & $>1000$ \\
\hline
\end{tabular}

"The definitions of the different Technical Performance Categories according to IWA are as follows:

Category A1: World class NRW management performance; the potential for further NRW reductions is small unless there is still potential for pressure reductions or the accuracy improvement of large customer meters.

Category A2: Further NRW reduction may be uneconomic unless there are water shortages or very high water tariffs; a detailed water audit is required to identify costeffective improvements.

Category B: Potential for marked improvements; establish a water balance to quantify the components of NRW; consider pressure management, better active leakage control practices, and better network maintenance; improve customer meter management, review meter reading, data handling and billing processed and identify improvement potentials.

Category C: Poor NRW record; tolerable only if water is plentiful and cheap; even then, analyse level and causes of NRW and intensify NRW reduction efforts.

Category D: Highly inefficient; a comprehensive NRW reduction program is imperative and high-priority." 
Mehmet Can Güçlü, Burak Ekinci, Aslıhan Korkmaz, Yusuf Başaran, Yakup Karaaslan,

Serdar Aldemir, Ayhan Türkoğlu, Ali Serindă̆, Jose Alberto Colino Fernandez, Kerem Ar, Baki Ülgen, Bilal Dikmen, Bekir Pakdemirli

Turkish Journal of Water Science \& Management 5 (1) (2021) / 2 - 39

\section{Table A3}

Population Projection Results for the Project Area

\begin{tabular}{|c|c|c|c|c|c|c|c|}
\hline Year & Marmaris & Armutalan & Beldibi & İçmeler & Adaköy & Yeşilbelde & $\begin{array}{c}\text { Total } \\
\text { Population }\end{array}$ \\
\hline 2016 & 35,081 & 20,749 & 10,376 & 5,863 & 3,958 & 232 & 76,259 \\
\hline 2017 & 36,049 & 21,439 & 10,680 & 6,016 & 4,052 & 234 & 78,470 \\
\hline 2018 & 37,044 & 22,135 & 10,986 & 6,169 & 4,149 & 237 & 80,720 \\
\hline 2019 & 38,066 & 22,837 & 11,293 & 6,322 & 4,248 & 239 & 83,005 \\
\hline 2020 & 39,117 & 23,545 & 11,601 & 6,475 & 4,349 & 241 & 85,328 \\
\hline 2021 & 40,196 & 24,257 & 11,909 & 6,628 & 4,452 & 244 & 87,686 \\
\hline 2022 & 41,306 & 24,972 & 12,218 & 6,781 & 4,558 & 246 & 90,081 \\
\hline 2023 & 42,445 & 25,690 & 12,526 & 6,934 & 4,667 & 249 & 92,511 \\
\hline 2024 & 43,617 & 26,409 & 12,833 & 7,087 & 4,778 & 251 & 94,975 \\
\hline 2025 & 44,821 & 27,128 & 13,139 & 7,240 & 4,892 & 254 & 97,474 \\
\hline 2026 & 46,057 & 27,847 & 13,444 & 7,393 & 5,009 & 256 & 100,006 \\
\hline 2027 & 47,328 & 28,564 & 13,746 & 7,546 & 5,128 & 259 & 102,571 \\
\hline 2028 & 48,635 & 29,278 & 14,046 & 7,699 & 5,250 & 261 & 105,169 \\
\hline 2029 & 49,977 & 29,988 & 14,343 & 7,852 & 5,375 & 264 & 107,799 \\
\hline 2030 & 51,356 & 30,693 & 14,636 & 8,005 & 5,503 & 267 & 110,460 \\
\hline 2031 & 52,773 & 31,391 & 14,925 & 8,158 & 5,634 & 269 & 113,150 \\
\hline 2032 & 54,230 & 32,081 & 15,210 & 8,311 & 5,768 & 272 & 115,872 \\
\hline 2033 & 55,726 & 32,763 & 15,490 & 8,464 & 5,906 & 275 & 118,624 \\
\hline 2034 & 57,264 & 33,435 & 15,765 & 8,617 & 6,046 & 278 & 121,405 \\
\hline 2035 & 58,844 & 34,095 & 16,034 & 8,770 & 6,190 & 280 & 124,213 \\
\hline 2036 & 60,468 & 34,743 & 16,296 & 8,923 & 6,338 & 283 & 127,051 \\
\hline 2037 & 62,137 & 35,377 & 16,552 & 9,076 & 6,489 & 286 & 129,917 \\
\hline 2038 & 63,852 & 35,996 & 16,800 & 9,229 & 6,643 & 289 & 132,809 \\
\hline
\end{tabular}


Mehmet Can Gü̧̧ü, Burak Ekinci, Aslıhan Korkmaz, Yusuf Başaran, Yakup Karaaslan,

Serdar Aldemir, Ayhan Türkoğlu, Ali Serindă̆, Jose Alberto Colino Fernandez, Kerem Ar, Baki Ülgen, Bilal Dikmen, Bekir Pakdemirli

Turkish Journal of Water Science \& Management 5 (1) (2021) / 2 - 39

\section{Figure A1}

Comparison of Storage Tank Outflows with and without Pressure Management
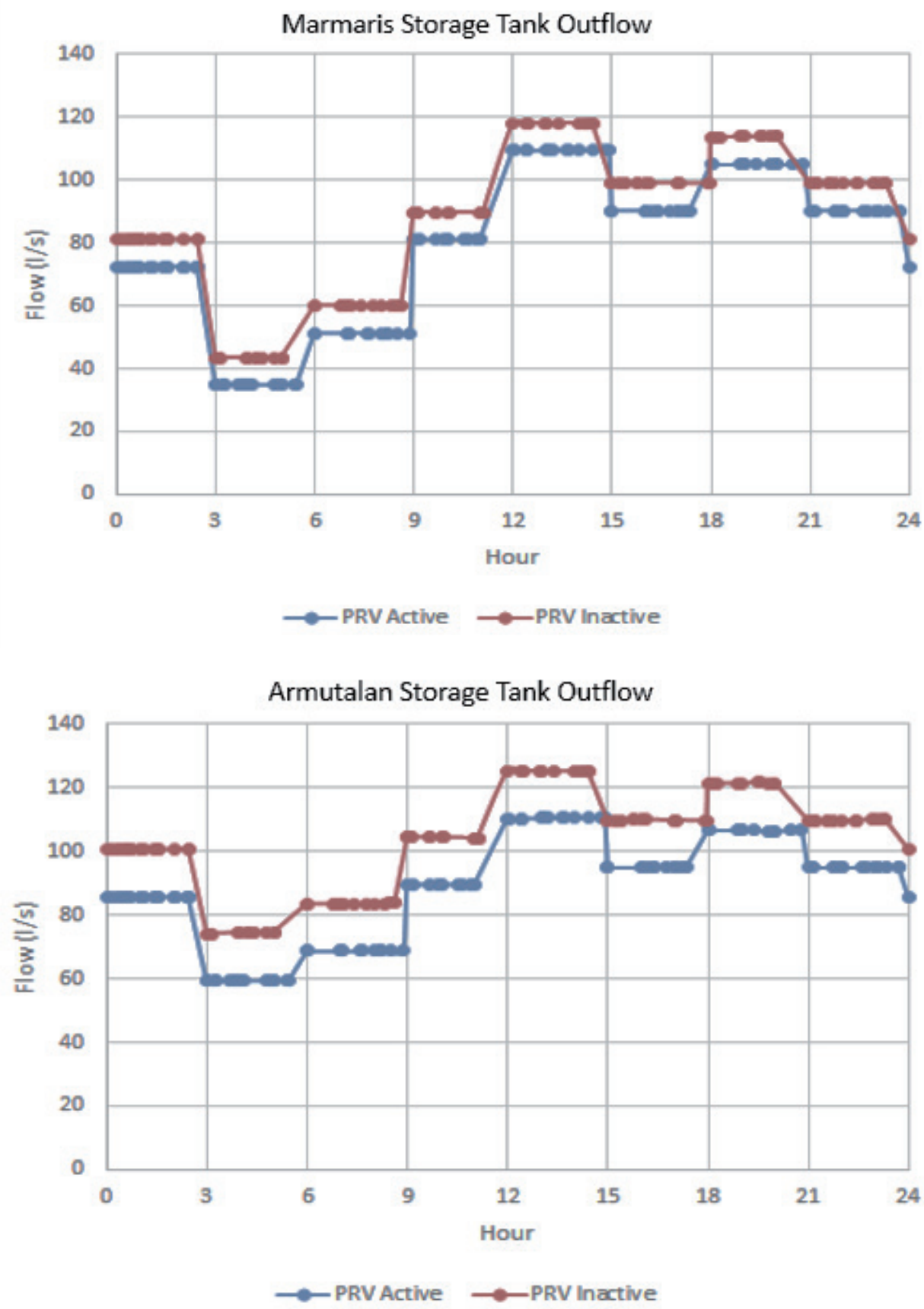
Mehmet Can Güçlü, Burak Ekinci, Aslıhan Korkmaz, Yusuf Başaran, Yakup Karaaslan,

Serdar Aldemir, Ayhan Türkoğlu, Ali Serindăg, Jose Alberto Colino Fernandez, Kerem Ar, Baki Ülgen, Bilal Dikmen, Bekir Pakdemirli

Turkish Journal of Water Science \& Management 5 (1) (2021) / 2 - 39
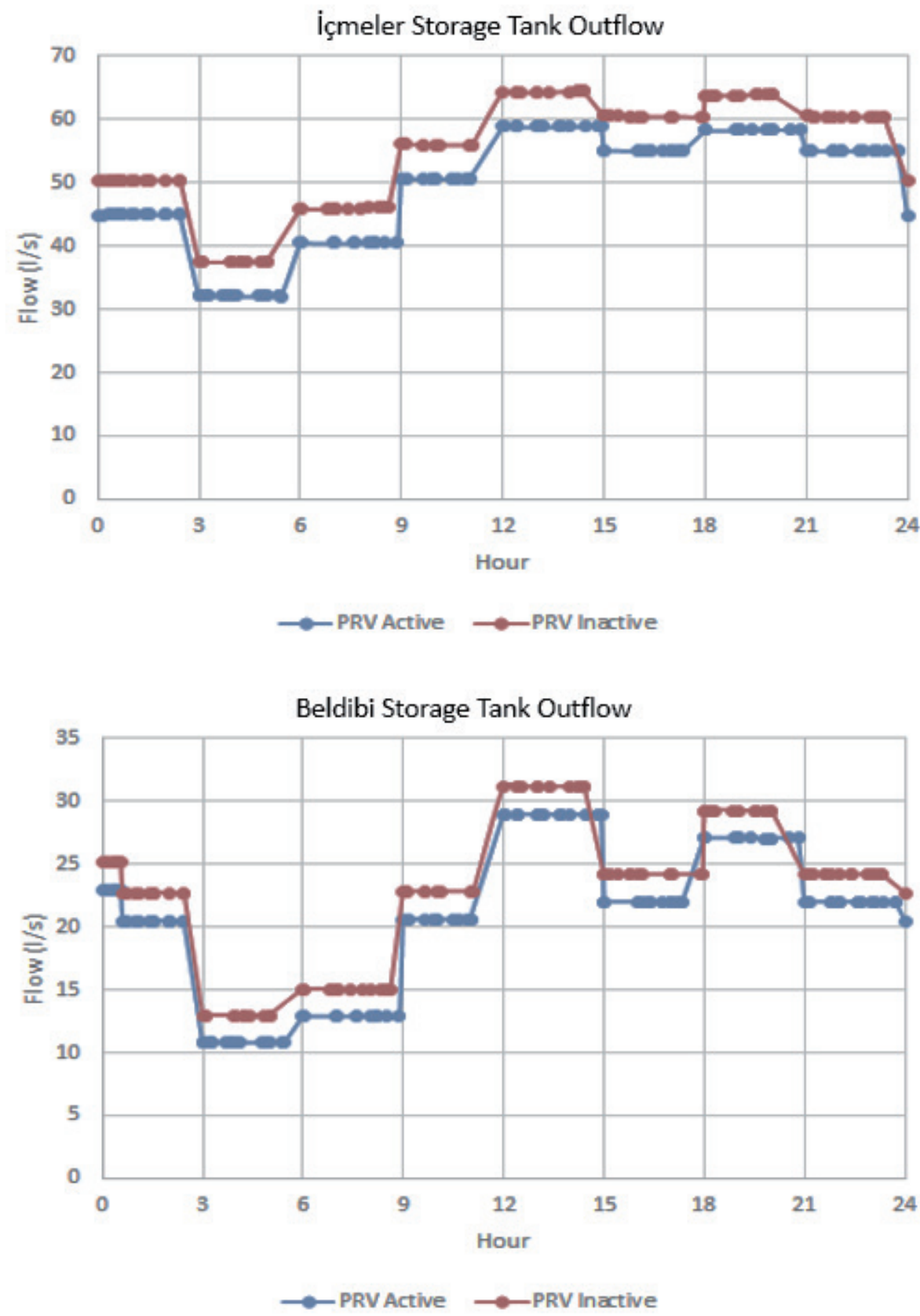


\section{Extended Turkish Abstract} (Genişletilmiş Türkçe Özet)

\section{Kentsel Su Temininin Verimliliğinin Artırılmasına İlişskin Fizibilite Çalışması}

Bu çalışma için 2018 yılına ait adrese dayalı nüfus kayıt sistemine göre toplam nüfusu 79.296 kişi olan Marmaris ilçesi örnek alan olarak seçilmiştir. 2018 verilerine göre, içme suyu arıtma tesisinden sağlanan yıllık su miktarı $14.184 .650 \mathrm{~m}^{3}$ tür ve sadece $8.853 .413 \mathrm{~m}^{3}$ '̈̈ izinli tüketim olarak kabul edilmektedir $(\% 62,4)$. İçme suyu arıtma tesisinden sağlanan yıllık su miktarının $8.131 .491 \mathrm{~m}^{3}$ 'ü faturalandırıldığından Gelir Getirmeyen Su (GGS) oranı \%42,7'dir. GGS'nin ana bileşenini, \%28,9 ile fiziki kayıplar, \%8,7 ile idari kayıplar ve \%5,1 ile faturalandırılmamış izinsiz tüketimler oluşturmaktadır. Tamamıyla fiziki ve idari kayıpların toplamından ibaret olan su kaybının oranı ise \%37,6'dır. GGS ve teknik performans kategorilerinin Uluslararası Su Birliği (International Water Association) sınıflandırmasına göre, sistem C kategorisinde performans göstermektedir. Bu, sistemin zayıf bir GGS'ye sahip olduğu ve sadece suyun bol ve ucuz olduğu durumlarda tolere edilebileceği anlamına gelmektedir. Ayrıca, fiziki kayıp kategorisi yoğun sızıntı azaltma çabalarının gerekli olduğunu göstermektedir. Çalışma kapsamında projeli ve projesiz olmak üzere iki senaryo üzerinden projenin baz yılı olan 2018'den projenin hedef yılı olan 2038'e kadar değerlendirme yapılmıştır. Projeli senaryo ile, planlanan proje kapsamında yapılacak yatırımların yanı sıra hem su temin sistemini hem de hedef yıla kadar artacak olan su ihtiyacinı karşılamaya yetecek düzeyde tutmak için gerekli yatırımlar dikkate alınmakta iken projesiz senaryo ise, su temin sisteminin kapasitesini artırmaya yönelik hiçbir yatırımın yapılmadığı temel durum senaryosudur. Başka bir deyişle, şebekede ve isale hattında herhangi bir genişleme yapılmayacak, herhangi bir su deposu inşa edilmeyecek ve İçme Suyu Arıtma Tesisi (İAT) bünyesinde üretim kapasitesini artırmaya yönelik ilave birim inşa edilmeyecektir. Diğer yandan, su sisteminin mevcut hizmet seviyesini korumak için ekonomik ömrünü tamamlamış pompaların yenileriyle değiştirilmesi gibi gerekli yatırımlar dikkate alınmıştır. Projesiz senaryo ile, 2034 yılından itibaren talebin karşılanamayacağı öngörülmekte olup gelecekteki taleplerin karşılanması adına tavsiye edilen tedbirlerin gerçekleştirilmesi önerilmektedir.

$\mathrm{Bu}$ çalışma, Marmaris su temini sisteminde bazı tedbirlerin alınması gerektiğine işaret etmektedir. Büyükşehir belediyelerindeki toplam su kayıplarının (fiziki kayıp ve idari kayıp) hedeflenen yıllarda belirlenen değerlere ulaşmasını hüküm altına alan "İ̧̧me Suyu Temin ve Dağıtım Sistemlerindeki Su Kayıplarının Kontrolü Yönetmelik” ine uymak için hem fiziki hem de idari kayıpların azaltılması gerekmektedir.

Bunun için ilk olarak, yüksek basınçlar, şebekeye basınç düşürücü vanaların takılması gibi iyi mühendislik uygulamaları ile kontrol edilmelidir. Buna ek olarak, İzole Alt Bölge (İAB) ile sınırları içerisinde olası sızıntıların tespit edilmesi ve izlenmesi, Basınç Yönetim Alanları (BYA) ile de şebekedeki basıncın izlenmesi kolaylaştırılmaktadır. Yüksek basınç kontrol sistemleri aynı zamanda altyapı rehabilitasyon önlemlerini de gerektirir. Asbest ve PVC borularının yüksek sızıntı ve patlama problemlerine neden olmalarından dolayı, şebekenin yüksek basınca maruz kalan bölümleri düktil, çelik gibi daha dayanıklı borularla değiştirilebilir. Altyapı rehabilitasyonu: Su verimliliği için şebeke cihazları, vanalar, basınç göstergeleri ve debi ölçerler gibi cihazlar su sisteminin yeniden inşasını ve/veya farklı unsurların eklenerek iyileştirilmesini içermelidir. Ayrıca, yönetim sisteminin iyileştirilerek izinsiz tüketim ve ölçüm yanlışlıklarının giderilmesi ve sayaç/faturalama hatalarının en aza indirgenmesi gerekmektedir. Marmaris'teki su sisteminin yönetimi ile ilgili diğer bir konu ise, şebekenin sınırlı bir şekilde izlendiği mevcut SCADA sisteminin iyileştirilmesinin gerekliliğidir.

Projeli senaryo için toplam öngörülen yatırım maliyeti $2.956 .739,26 €$ olup, 2021 ve 2022 yıllarında yatırımın uygulanması öngörülmektedir. Yatırımların tamamlanmasının ardından Muğla Su ve Kanalizasyon İdaresi'nin kapsamlı SCADA uygulaması ile hidrolik modeli kalibre etmesi tavsiye edilmektedir. Modellerin hidrant açıklıkları gibi yüksek akış koşullarında daha doğru kalibre edildiği 
Mehmet Can Güçlü, Burak Ekinci, Aslıhan Korkmaz, Yusuf Başaran, Yakup Karaaslan,

Serdar Aldemir, Ayhan Türkoğlu, Ali Serindă̆, Jose Alberto Colino Fernandez, Kerem Ar, Baki Ülgen, Bilal Dikmen, Bekir Pakdemirli

Turkish Journal of Water Science \& Management 5 (1) (2021) / 2 - 39

bilinmektedir. Bu nedenle, bir İAB kalibre edilirken, birkaç hidrantta birden fazla saha testi yapılmalıdır. Ek olarak, akış ölçer bölmesinden ayrı hidrant seçimi, kalibrasyonun doğruluğunu arttırmaktadır.

Fayda-maliyet analizi, projeli senaryo için pozitif olmakla birlikte, projesiz senaryoda net bugünkü değer için negatif sonuçlar görülmektedir. Ayrıca, su verimliliğini artırmaya yönelik çalışmaların 2021 ve 2022 yıllarında yapılacak olması nedeniyle yatırım maliyetinin olumsuz etkileri de bu dönemde olacaktır. İç karlılık oranı ile ilgili olarak, 2038 yılına ilişkin sonuçlar projesiz senaryo için \%1 ve projeli senaryo için ise \%14'tür. Yatırımın geri ödeme süresi 5,5 yıldır (2027) ve \%10 iskontolu geri ödeme süresi ise 6,8 yıldır (2028). Finansal analize ilişkin üç gösterge (iç karlılık oranı, net bugünkü değer, geri ödeme süresi), proje de önerilen yatıımların uygulanmasının yararını açıkça göstermektedir.

Sistemin verimliliğindeki iyileşmenin suyun birim fiyatı üzerindeki etkisine ilişkin olarak iki farklı değerlendirme gerçekleştirilmiştir: bunlardan biri 2021 ve 2022 arasında yatırımın dağıtıldığı, diğeri ise toplam yatırımın proje süresi boyunca dağıtıldığı senaryolardır. Sonuç olarak, suyun birim maliyetinin mevcut durumda $1,31 € / \mathrm{m}^{3}$ ten aşağıda verilen değerlere dönüşeceği hesaplanmıştır:

- Projesiz senaryo için; 2033 'te $\mathbf{1 , 2 1} € / \mathbf{m}^{\mathbf{3}}$ (minimum fiyat) ve $2038^{\prime}$ de $\mathbf{1 , 3 0} € / \mathbf{m}^{\mathbf{3}}$,

- Projeli senaryo için (yatırımın 2021-2022 yıllarında dağıtılması durumunda), 2021 ve 2022 yıllarında sirasıyla $1,31 € / \mathbf{m}^{3}$ ve $\mathbf{1 , 2 5} € / \mathbf{m}^{3}, 2038$ yılında ise $\mathbf{1 , 0 0} € / \mathbf{m}^{3}$,

- Projeli senaryo için (yatırımın 2021-2038 olan proje ömrüne dağıtılması durumunda), 2038 yilında $1,00 € / \mathbf{m}^{3}$.

Her iki senaryoya baktığımızda projeli senaryoda suyun birim fiyatındaki düşüşün, projesiz senaryodakinden açık bir şekilde daha fazla olduğunu görürüz. Bu nedenle, fizibilite çalışması kapsamında önerilen yatırımların uygulanması tavsiye edilmektedir.

Ayrıca, hidrolik modelleme, SCADA ve finansal analiz çalışmalarına ek olarak, içme-kullanma suyu sektöründe verimliliği artırmak için bazı tamamlayıcı tedbirler belirlenmiş̧ir. Bunlar; idari kayıpları azaltma planı, personel kapasite geliştirme planı, su tasarrufu bilinci kazandırma kampanyaları ve tarife ile ilgili tedbirlerdir.

Son olarak, kentsel su temini sektörüne ilişkin verimliliğin arttırılmasıyla ilgili olarak gelecekte yapılacak çalışmalar için bazı öneriler aşağıda yer almaktadır:

$\checkmark \quad$ Daha geniş bir ölçekte sistemi daha verimli bir şekilde kontrol etmek için Su Dengesi Tablosunun daha yüksek hassasiyetle hazırlanması gerekmektedir.

$\checkmark$ Hidrolik modeller, su temin sistemleri gibi karmaşık su sistem koşullarını anlamak ve sistemdeki iyileştirmelere ilişkin harekete geçmek için analitik bir araç olarak kullanılmalıdır.

$\checkmark$ SCADA, sistemi uzaktan izlemek, kontrol etmek ve model kalibrasyonunda kullanmak için önerilmektedir.

$\checkmark \quad$ Su idareleri aktif olarak kaçak tespit çalışmalarını yürütmeli ve devamlı kaçak tespiti için ekipler oluşturmalıdır.

$\checkmark$ Çalışma kapsamında belirtilen tedbirlere ek olarak, kapasite geliştirme ve farkındalık artırma kampanyaları gibi diğer tamamlayıcı tedbirler de alınmalıdır.

$\checkmark$ Bütüncül değerlendirme yöntemi ile daha ayrıntılı sistem analizi yapmak faydalı olacaktır. Hidrolik modelleme, finansal ve sosyal analizlerle beraber yaşam döngüsü analizinden de yararlanılarak, gelecekteki çevresel ve iklimsel değişikliklere yönelik sektörel adaptasyon stratejileri de değerlendirilmelidir. 